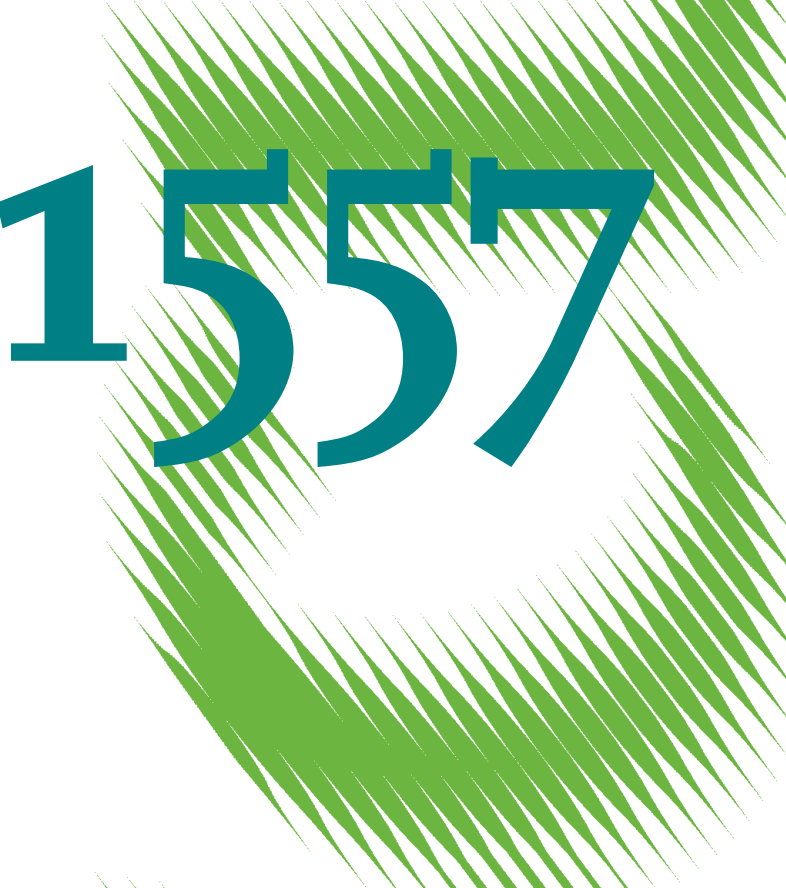

The Bank Lending Channel in a Dual Banking System

Evidence from Malaysia 
Opinions expressed in this paper are those of the author(s) and do not necessarily reflect views of the institute.

IMPRESSUM

(C) DIW Berlin, 2016

DIW Berlin

German Institute for Economic Research

Mohrenstr. 58

10117 Berlin

Tel. +49 (30) $89789-0$

Fax +49 (30) $89789-200$

http://www.diw.de

ISSN electronic edition 1619-4535

Papers can be downloaded free of charge from the DIW Berlin website:

http://www.diw.de/discussionpapers

Discussion Papers of DIW Berlin are indexed in RePEc and SSRN:

http://ideas.repec.org/s/diw/diwwpp.html

http://www.ssrn.com/link/DIW-Berlin-German-Inst-Econ-Res.html 


\title{
The Bank Lending Channel in a Dual Banking System: \\ Evidence from Malaysia
}

\author{
Guglielmo Maria Caporale \\ Brunel University London
}

Abdurrahman Nazif Çatık

Ege University, Turkey

Mohamad Husam Helmi

Brunel University London

Faek Menla Ali

Brunel University London

Mohammad Tajik

Brunel University London

\section{March 2016}

\begin{abstract}
This paper examines the bank lending channel of monetary transmission in Malaysia, a country with a dual banking system including both Islamic and conventional banks, over the period 1994:01-2015:06. A two-regime threshold vector autoregression (TVAR) model is estimated to take into account possible nonlinearities in the relationship between bank lending and monetary policy under different economic conditions. The results indicate that Islamic credit is less responsive than conventional credit to interest rate shocks in both the high and low growth regimes. By contrast, the relative importance of Islamic credit shocks in driving output growth is much greater in the low growth regime, their effects being positive. These findings can be interpreted in terms of the distinctive features of Islamic banks.
\end{abstract}

Keywords: Bank lending channel, Malaysia, Monetary transmission, Threshold VAR

JEL Classification: C32, E31, E42, E58

Corresponding author: Professor Guglielmo Maria Caporale, Research Professor at DIW Berlin. Department of Economics and Finance, Brunel University, London, UB8 3PH, UK. Tel.: +44 (0)1895 266713. Fax: +44 (0)1895 269770. Email: Guglielmo-Maria.Caporale@brunel.ac.uk 


\section{Introduction}

The transmission mechanism of monetary policy has been analysed extensively in numerous studies focusing on countries with conventional banking systems (e.g., Brunner and Meltzer, 1988; Bernanke and Gertler, 1995; Peersman and Smets, 2001, 2003; Kassim et al., 2009, Çatık and Martin, 2012; Ahmad and Pentecost, 2012; Fungácová et al., 2014). By contrast, there is very little evidence concerning economies with a dual (Islamic and conventional) banking system, where this mechanism might be rather different given the distinctive features of Islamic finance, such as the prohibition to charge a predetermined interest rate and the granting of credit only to productive projects (Iqbal, 2001; Chong and Liu, 2009): financing speculative activities is restricted since these are thought to cause an increase in the price level without contributing to the real economy, social justice and economic efficiency, which Islamic finance should promote according to Sharia law ${ }^{1}$ (Gulzar and Masih, 2015; Kammer et al., 2015; Caporale and Helmi, 2016). For instance, Khan and Mirakhor (1989) concluded that monetary policy shocks have less effect on Islamic banks because the profit and loss sharing (PLS) paradigm allows them to share risk with the depositors. Kassim et al. (2009) reported instead that credit is more sensitive to interest rate movements in the case of Islamic banks, which might make them more unstable. Sukmana and Kassim (2010) estimated a VAR model to analyse the role of Islamic banks in the transmission mechanism of monetary policy in the case of Malaysia, whilst Ergeç and Arslan (2013) examined the case of Turkey.

Islamic banks have grown very rapidly in recent years both in size and in number, with more than 700 Islamic financial institutions operating in 85 countries across the Middle East, Asia, Europe and the US with approximately \$2.2 trillion Sharia-compliant assets in 2015 (expected to reach $\$ 3$ trillion in 2018). ${ }^{2}$ Of particular interest is the case of Malaysia, which has a dual (Islamic and conventional) banking system and one of the largest Islamic banking sectors in the world, accounting for around $16.7 \%$ of the Islamic finance global market in 2014 (Ernst and Young, 2014). It has had well-established Islamic financial institutions for over 30 years, with the share of Islamic finance growing from $0.073 \%$ in 1994 to $26.207 \%$ in 2015Q2 at a compounded annual growth rate of $38.3 \%$ compared to $7.9 \%$ for conventional banks. Islamic banks are expected to grow at a yearly rate of $18 \%$ for the next five years (see Table 1 in the Appendix), with the Malaysian authorities planning to increase their market

\footnotetext{
${ }^{1}$ Sharia law is based on the Quran, the hadith and Islamic jurisprudence developed by many Muslim scholars.

${ }^{2}$ For more details, see Chong and Liu (2009), Abedifar et al. (2013), and Ernst and Young (2016).
} 
share to $40 \%$ of total financing by 2020 and aiming to make the country an international hub for Islamic finance (BNM, 2012). ${ }^{3}$

This paper analyses the transmission mechanism of monetary policy in Malaysia using a nonlinear framework, in contrast to most of existing empirical studies, that have employed instead linear econometric techniques (see, e.g., Kassim et al., 2009; Sukmana and Kassim, 2010; Ergeç and Arslan, 2013; Gulzar and Masih, 2015). The adopted econometric framework is a two-regime threshold VAR (TVAR) model, with the output gap being used as the threshold variable. This model has several interesting features that make it particularly suitable for analysing the impact of monetary policy on bank lending behaviour. First, it allows for potential nonlinearities in the responses to monetary policy shocks, which is crucial since the impact of the latter may depend upon the macroeconomic conditions. Second, since the threshold variable is treated as an endogenous variable, regime switches resulting from structural shocks can also be captured (Atanasova, 2003; Balke, 2000): the impulse response functions in a TVAR model depend on the size and sign of shocks as well as the state of the economy.

Our results show that the bank lending channel is indeed state-dependent in Malaysia. More specifically, Islamic credit is found to be less responsive than conventional credit to interest rate shocks in both high and low growth regimes. By contrast, the relative importance of Islamic credit shocks in driving output growth is much greater in the low growth regime, their effects being positive.

The paper is organised as follows: Section 2 reviews Islamic finance and the different role of Islamic and conventional banks in the bank lending channel of monetary policy; Section 3 describes the data and provides a preliminary analysis; Section 4 outlines the methodology; Section 5 discusses the empirical results; finally, Section 6 offers some concluding remarks.

\section{Islamic Finance and the Bank Lending Channel}

\subsection{Islamic Finance}

Although Islamic banks share some features with conventional financial intermediaries, they differ from the latter in that they operate on the basis of the Sharia principles outlined in the

\footnotetext{
${ }^{3}$ Malaysia is classified as a foremost international hub for Islamic finance with the largest Sukuk market in the world, and it is the centre for major international financial groups providing Islamic financial products and services (BNM, 2015; IMF, 2014).
} 
Quran, the hadith ${ }^{4}$ and Islamic jurisprudence, with the ex-post PLS rate replacing the predetermined rate of commercial banks (Iqbal, 2001; Chong and Liu, 2009). The prohibition of the conventional ex-ante interest rate is seen as instrumental to improving both social justice and economic efficiency (El-Gamal, 2006; Berg and Kim, 2014). That is, Islamic banking is a case of ethical finance and hence it has economic implications for systemic stability and the distribution of credit risk, since the productivity of the project, rather than the creditworthiness of borrowers (as in the case of conventional banks) is the main factor determining the allocation of credit (see Di Mauro et al., 2013).

Another important feature of Islamic banks is that they are not allowed to engage in any speculative transactions such as derivatives, toxic assets and gambling, which are not compliant with Sharia principles (Beck et al., 2013). It is reckoned that financing such activities is responsible for many financial crises and normally causes an increase in the price level rather than contributing to real activities in the economy (Di Mauro et al., 2013). Speculative investments make conventional banks "risk transferring" while Islamic banks are "risk sharing" (see Hasan and Dridi, 2010). By contrast, Islamic banks only provide credit to finance productive investment rather than speculative activities (Gulzar and Masih, 2015; Kammer et al., 2015). Each financial transaction is underpinned by an existing or potential real asset, whilst conventional banks can provide credit without such constraints (see Siddiqi, 1999, 2006 and Askari, 2012). In addition, Islamic banks cannot generate profit based on pure financing so they must engage, for instance, in investment or sale transactions and share both the return and the risk of the contract (Baele et al., 2014).

\subsection{Islamic Financial Contracts ${ }^{5}$}

Islamic financial contracts are designed according to the PLS principle. For instance, Musharaka (partnership) is based on the idea of equity participation. Under this contract, each participant pays for a percentage of the capital in the company. The profits or losses generated from the business are then shared between the owners on the basis of an agreed profits and losses share called the PLS ratio (Ariff, 1988). In the case of Mudharabah (profitsharing), one party (Islamic bank) supplies all the required finances, while the other party (customer/entrepreneur) contributes the labour and management skills. Therefore, the bank is considered as a shareholder and any profit from the business is shared between the

\footnotetext{
${ }^{4}$ Hadith represents the actions and sayings of the prophet Mohammad, which are one of the main sources of Islamic guidance in many aspects of Muslim life including economic activities.

${ }^{5}$ For a detailed discussion, see Kettell (2010) and Baele et al. (2014).
} 
entrepreneur and the bank according to a pre-determined criterion (rather than as a percentage of the investment). The Islamic bank takes any losses, while the entrepreneur loses his/her reward on provision of labour (Haron et al., 1994 and Kettell, 2010). A third type of contract is known as Murabahah (cost plus): it is essentially the sale of a particular product, with the two parties agreeing on the price, the cost and the profit margin of the item. More specifically, Islamic banks purchase the product on the behalf of the customer and resell it to him/her at a marked-up price (Ariff, 1988; Haron et al., 1994). Finally, Ijarah (leasing) involves the transfer of usufruct at an agreed rent (rather than the ownership of the asset) to customers (Baele et al., 2014). The client approaches the bank to rent, for example, machinery, vehicles, or any other equipment and makes a promise to lease that equipment. The Islamic bank buys the machinery or any other equipment and leases it to its customers for an agreed rent. If the customer requires the bank to buy the equipment as well, the rent and a periodic instalment will be paid as a part of the purchase (Zaher and Hassan, 2001).

\subsection{Islamic vs. Conventional Banks and the Bank Lending Channel}

Only a few studies have examined monetary policy transmission mechanism in countries with both conventional and Islamic banks, and considered Islamic financial instruments, financial stability, liquidity and risk management in such economies (see Cihák and Hesse, 2010; Beck et al., 2013, Abedifar et al., 2013 and Yousuf et al., 2014).

Cihák and Hesse (2010) used cross-country data to assess whether Islamic banks play a positive role in the financial stability of the banking system. They compared small-size Islamic and conventional banks and found that, on average, the former are more stable than the latter. However, this is not the case for larger banks: as the size of Islamic banks increases, their financial stability decreases since credit risk management becomes more difficult in the presence of limited and risky investment opportunities.

Çevik and Charap (2011) examined the causal relationship between the conventional deposit rates and Islamic PLS rates in Malaysia and Turkey. They found that these two variables exhibit cointegration, with the former Granger-causing the latter but not vice versa. Chong and Liu (2009) also reported that the PLS rates mimic the movement of conventional ones in Malaysia. Kassim and Manap (2008) carried out causality tests using the Toda-Yamamoto method to analyse the information content of the Islamic interbank money market rate 
$\left(\right.$ IIMMR) ${ }^{6}$ and the conventional interbank money market rate (CIMMR) in Malaysia; they concluded that the information in the former can explain movements in total bank loans and the real exchange rate and suggested that this rate should be adopted as a monetary policy instrument by the Malaysian authorities.

Sukmana and Kassim (2010) used a VAR framework and found significant evidence that Islamic banks in Malaysia contribute to the transmission of monetary policy shocks to the real economy through the banking channel. More recently, Ergeç and Arslan (2013) showed in the context of a vector error correction model (VECM) that movements in the overnight interest rate have asymmetric effects on Islamic and conventional banks in Turkey: for instance, a positive interest rate shock leads to an increase (decrease) in the level of deposits in conventional (Islamic) banks.

Kassim et al. (2009) estimated a vector autoregression (VAR) model and found that loans and deposits are more responsive to interest rate changes in the case of Islamic as opposed to commercial banks in Malaysia, which makes the former less stable financially (see also Rosly, 1999). By contrast, Khan and Mirakhor (1989) argued that Islamic banks are less affected by monetary shocks (and therefore are more stable) than conventional banks, the reason being that profit and loss sharing allows Islamic banks to transfer part of the risk to the depositors (Hassan, 2006; Said, 2012, Ghassan et al., 2013).

Çatık and Martin (2012) extended the work of Çatık and Karaçuka (2012) by using a TVAR model to analyse different monetary transmission mechanisms; however, they did not consider the possible role of Islamic finance. They found that the response to macroeconomic shocks has become different in Turkey compared to other market economies following the introduction of inflation targeting.

None of the studies mentioned above examines the monetary transmission mechanism in countries with a dual banking system (including both Islamic and conventional banks) allowing for possible nonlinearities. The present paper aims to fill this gap in the literature.

\section{Data Description and Preliminary Analysis}

To investigate the bank lending channel of monetary policy in the dual banking system of Malaysia, we collected monthly data for Islamic credit and conventional credit from the

\footnotetext{
${ }^{6}$ The IIMMR rate is based on Mudharabah Interbank Investment Scheme (Gan and Yu, 2009).
} 
National Bank of Malaysia. In addition, data on the money supply (M2), the consumer price index (CPI), the industrial production index (IPI), and the overnight policy rate (I) were retrieved from the IMF's International Financial Statistics (IFS). The resulting sample includes 258 monthly observations over the period 1994:01-2015:06.

In order to examine the time series properties of the variables under consideration, a battery of unit root tests were carried out. In addition to the conventional augmented Dickey-Fuller (ADF) and Phillips-Perron (1988) tests, we also performed the Lee and Strazicich (2003) one allowing for two structural breaks to take into account the possible impact of the global and local crises on the degree of integration of the series. ${ }^{7}$ The results of the Lee and Strazicich (2003) test, reported in Table 2 in the Appendix, confirm those of the ADF and PP tests and suggest that all variables can be treated as I(1), and therefore they are entered into the VAR/TVAR models in first differences. The break dates mainly correspond to the 1997-98 Asian financial crisis and the 2007-8 recent global financial crisis; in the case of the exogenous variables there appears to be an additional break coinciding with the 2001 dotcom bubble crisis in the US.

A wide range of descriptive statistics are reported in Table 3. The means of monthly total, conventional, and Islamic credit changes are all positive. The highest is that of Islamic credit changes, which highlights its sharp growth relative to conventional credit over the sample period. All other means are also positive, except that of policy rate changes, which is negative and small. Islamic credit changes are more volatile than both total and conventional credit changes, and both interest rate changes and industrial production growth are more volatile than inflation and money growth. Most variables exhibit skewness (positive in all cases, with the exception of policy rate changes) and excess kurtosis. The Jarque-Bera (JB) test statistics imply a rejection at the $5 \%$ level of the null hypothesis of normality.

\section{The Model}

The VAR approach is the most frequently used in the literature investigating the monetary transmission mechanism. Its advantage is that it does not require imposing possibly arbitrary exclusion restrictions, an issue even more relevant in the case of emerging countries whose economic structure is less well known (Mishra and Montiel, 2012). Further, it estimates the

\footnotetext{
${ }^{7}$ These test results of the ADF and the Phillips-Perron (1988) are not reported but are available upon request.
} 
dynamic response of the system to a shock without debatable identification restrictions (Sims, 1980). Following Bernanke and Blinder (1992), linear VAR models are often estimated. However, since monetary policy is designed differently during economic expansion (growth) and contraction (recession) phases, a nonlinear specification is more appropriate. Therefore, we investigate the bank lending channel in Malaysia by estimating a TVAR model, which is an extension of the linear VAR model in which the economy has two regimes and switches between them depending on the optimum value of the threshold variable. A two-regime TVAR model is specified as follows (Atanasova, 2003; Balke, 2000):

$$
\begin{aligned}
Y_{t}= & I\left[c_{t-d} \geq \gamma\right]\left(A_{0}^{1}+\sum_{i=1}^{p} B_{t}^{1} Y_{t-i}+\sum_{i=1}^{q} C_{t}^{1} X_{t-i}\right)+I\left[c_{t-d}<\gamma\right]\left(A_{0}^{2}+\sum_{i=1}^{p} B_{t}^{2} Y_{t-i}+\right. \\
& \left.\sum_{i=1}^{q} C_{t}^{2} X_{t-i}\right)+\varepsilon_{t}
\end{aligned}
$$

where $Y_{t}$ and $X_{t}$ stand for the vectors of endogenous and exogenous variables respectively, $A_{0}$ is the vector of intercept terms, $B_{t}$ and $C_{t}$ are parameter matrices, $p$ and $q$ are the lag orders of the endogenous and exogenous variables, and $\varepsilon_{t}$ is the vector of innovations with a variance covariance matrix of $E\left(\varepsilon_{t} \varepsilon_{t}^{\prime}\right)=\sum$. Given that we use three alternative measures for credit (in logs), namely total credit $\left(\right.$ ltcre $\left._{t}\right)$, Islamic credit $\left(\right.$ licre $\left._{t}\right)$, and commercial or conventional credit $\left(\right.$ lccre $\left._{t}\right)$, three different vectors of endogenous variables are used as follows:

Model 1: $Y_{1, t}^{\prime}=\left[\Delta l m 2_{t}, \Delta\right.$ int $_{t}, \Delta$ ltcre $_{t}, \Delta l c p i_{t}, \Delta$ lipi $\left._{t}\right]$

Model 2: $Y_{2, t}^{\prime}=\left[\Delta \operatorname{lm} 2_{t}, \Delta\right.$ int $_{t}, \Delta$ lccre $_{t}, \Delta$ lcpi $\left._{t}, \Delta \operatorname{lipi}_{t}\right]$,

Model 3: $Y_{3, t}^{\prime}=\left[\Delta l m 2_{t}, \Delta i n t_{t}, \Delta\right.$ licre $_{t}, \Delta$ lcpi $\left._{t}, \Delta \operatorname{lipi}_{t}\right]$,

where $\Delta$ is the first difference operator, $i n t_{t}$ stands for the interbank rate, $\operatorname{lm} 2_{t}$ denotes the $\log$ of money supply M2, $l c p i_{t}$ is the $\log$ of the consumer price index. Since GDP data are not available on a monthly basis, the log of the industrial production index, denoted by lipi $i_{t}$, is used as a proxy for economic activity. 
In order to capture the possible effects of global developments on the conduct of monetary policy, the following exogenous variables are included when each of the above vectors of the endogenous variables are estimated (Peersman and Smets, 2003):

$X_{t}^{\prime}=\left[\right.$ lcompri $_{t}, \Delta f f r_{t}, \Delta$ lipius $_{t}, \Delta$ lner $\left._{t}\right]$,

where lcompri $_{t}$ is the log of the world commodity price index (included to take into account the "price puzzle" as in Gorden and Leeper (1994)), $f f r_{t}$ is the US federal funds rate, lipius $t_{t}$ is the log of the US industrial production index, and, lner $_{t}$ is the log of the domestic nominal exchange rate vis-à-vis the US dollar.

Further, $c$ is the threshold variable and $\gamma$ is the optimum value of the threshold; $I[$.$] is the$ dummy indicator function that equals 1 when $c_{t-d} \geq \gamma$, and 0 otherwise. $c_{t-d}$ is the threshold variable lagged by $d$ periods. The threshold variable is often defined as the moving average of one of the endogenous variables in $Y_{t}$ (see for example Balke, 2000; Calza and Sousa, 2006). In our case, it is the twenty-four month moving average of the IPI growth rate, $\operatorname{magr}_{t-d}$ (see Figure 1 in the Appendix). ${ }^{8}$

Equation (1) indicates that the economy is in regime 1 when the threshold variable exceeds or is equal to the optimal threshold value $\geq \gamma$, otherwise it is in regime 2 . If there is no significant difference between the estimated parameters $A_{0}^{1}=A_{0}^{2}, B_{i}^{1}=B_{i}^{2}, C_{i}^{1}=C_{i}^{2}$, the threshold model reduces to a linear VAR one.

The regime switching parameters $\left(A_{i}^{1}, A_{i}^{2}, B_{i}^{1}, B_{i}^{2}, C_{i}^{1}\right.$, and $\left.C_{i}^{2}\right)$, the threshold value $(\gamma)$ and the delay parameter $(d)$ can all be estimated endogenously within this framework. First, the optimum number of lags of the endogenous and exogenous variables is determined on the basis of model selection criteria. Then, the existence of a threshold effect in a multivariate framework is tested using the $C(d)$ statistic introduced by Tsay (1998), which is a multivariate extension of Tsay's (1989) nonlinearity test. The procedure is the following: the variables are ordered according to increasing values of the threshold variable, $\operatorname{magr}_{t}$, then the VAR model is estimated recursively starting from the first $m_{0}$ observations; finally, the test statistic is calculated by regressing the residuals on the explanatory variables, and testing for the joint significance of the latter. If the model is linear, the residuals should be

\footnotetext{
${ }^{8}$ The Hodrick-Prescott filter of industrial production index is also used as an alternative threshold variable. C(d) test results yield very similar regime classifications, leading to qualitatively the same impulse responses and variance decompositions. These results are available upon request.
} 
uncorrelated with the explanatory variables; under the null of linearity $H_{0}=A_{0}^{1}=A_{0}^{2}, B_{i}^{1}=$ $B_{i}^{2}, C_{i}^{1}=C_{i}^{2}$ the test statistic follows a chi-squared distribution with $k(p k+q v+1)$ degrees of freedom, $k$ and $v$ being the number of variables in the vectors of endogenous and exogenous variables respectively, and $p$ and $q$ the corresponding lag orders.

After the determination of the delay parameter, the $C(d)$ statistic is computed over the trimmed interval of the threshold parameter, $\left(c_{1}\right.$ and $\left.c_{2}\right)=[0.15,0.85]$, to maximise the probability of identifying the two regimes. Then, this interval is partitioned into grids, and the model is estimated for each grid. The grid, including the minimum selection criteria value, is selected as the optimal threshold value of the transition variable, $\gamma$. The impulse response functions and forecast error decompositions obtained from this model are nonlinear since the parameters are allowed to evolve over regimes.

\section{Empirical Results}

A pre-requisite to the estimation of the TVAR models is the computation of $C(d)$ statistics to uncover the presence of a threshold effect in a multivariate framework. The results from the recursive estimation based on the starting points of $m_{0}=25$ and $m_{0}=50$ and the delay parameters of $d=1,2,3,4$ and 5 are presented in Table 4 in the Appendix. Except the fourth and fifth lags of model 3 , the null hypothesis of linearity is rejected at the $5 \%$ significance level. This implies that there are two different regimes corresponding to different phases of the business cycle. The optimum delay parameter of the threshold variable, $\operatorname{magr}_{t-d}$, is estimated to be equal to 3 for all three TVAR specifications on the basis of the $\chi^{2}$ test statistic. Then, the interval containing the possible optimal threshold value of the $\operatorname{magr}_{t-d}$ [0.709 12.025] is partitioned into 500 grids, and the optimal threshold value for each TVAR model is obtained in the grid satisfying the minimum Akaike Information Criterion (AIC). The estimated threshold values of $5.561 \%, 5.558 \%$ and $5.556 \%$ for models 1,2 , and 3 , respectively, lead to very similar regime classifications. It is also noteworthy that the endogenously estimated optimal threshold values are slightly above the average growth rate of industrial production (5.294\%) over the investigation period. On that basis, regimes 1 and 2 can be defined as the upper and lower growth regimes respectively, since they contain observations above or below the optimal threshold. 
Having identified the regimes, generalized impulse response functions are estimated (see Figures 2 to 7) and forecast error variance decomposition analysis (see Tables 5 and 6 in the Appendix) is conducted for the three TVAR models. The results from a simple linear VAR model are also presented for comparison purposes. The responses, computed from the TVAR (model 1) and the corresponding VAR model (see Figures 2 and 3), illustrate the effects of positive interest rate changes and negative money supply changes (a monetary tightening) on output growth and inflation. They both lead to a decline in output growth as expected, their impact being greater when the economy is in the low growth regime. Negative money shocks result in lower inflation, especially in the low growth regime, whilst an increase in interest rates brings about higher inflation in the linear VAR model and the low (but not the high) growth regime in the TVAR model. ${ }^{9}$ This suggests that monetary authorities can achieve lower inflation by decreasing interest rates only when the economy is operating above its potential growth rate.

Figures 4 and 5 display the effects of a tightening in total, conventional and Islamic credit respectively on output growth and inflation based on the estimated linear and TVAR models. This generally leads to a decrease in both output growth and inflation. The impact on inflation is higher in the low than in the high growth regime. Total and conventional credit shocks have the same qualitative effects on output growth. Islamic credit shocks have a lower impact, in comparison to conventional credit, on both output growth and inflation in both regimes, this being more sizeable in the low growth regime. Possible explanations for these findings are the lower share of Islamic banking in the financial system of Malaysia, and also the principles of Islamic finance not allowing Islamic banks to engage in speculative activities (Hasan and Dridi, 2010; Khan, 2010; and Kammer et al., 2015). These results are consistent with those of Amar et al. (2015), who found that in Saudi Arabia Islamic banking credit has a positive effect on non-oil private output but not much of an impact on the price level.

Figure 6 shows the responses of total, conventional and Islamic credit changes to interest rate changes, obtained respectively from models 1,2 and 3. A positive interest rate shock generally leads to a decline in conventional and Islamic credit, especially when the economy operates in the low growth regime. In addition, Islamic credit appears to be less responsive than conventional credit to interest rate shocks in both regimes; this is consistent with the

\footnotetext{
${ }^{9}$ The results of the effects of positive interest rate and negative money supply shocks on output growth and inflation obtained from models 2 and 3 were qualitatively the same and are available upon available request.
} 
findings of Khan and Mirakhor (1989), who concluded that monetary policy shocks have less effect on Islamic banks because the PLS paradigm allows Islamic banks to share a percentage of risk with the depositors; by contrast, Kassim et al. (2009) found that in Malaysia Islamic loans and deposits are more responsive to interest rate changes than commercial ones. Further evidence is provided by Figure 7, which shows that negative money supply shocks lead to a smaller decline in Islamic credit in both regimes.

The forecast error variance decomposition analysis from the linear and TVAR models (see Tables 5 and 6 in the Appendix) corroborates the findings of the linear and threshold impulse responses by highlighting clear differences between the low and high growth regimes. Both the linear and threshold variance decomposition results imply that most of the forecast error variance of output growth and inflation is explained by their own shocks. The linear model might underestimate the contribution of credit changes, which appears to be much higher in the nonlinear model in both regimes. Conventional credit changes explain more of the variations in inflation, especially in the low growth regime, than Islamic credit changes that seem to play a relatively minor role (slightly greater in the high growth regime). For instance, in the low growth regime, over a 15-month horizon, conventional credit changes account for 8.4 percent of the total variation in inflation as opposed to 1.792 percent in the case of Islamic credit changes. This finding might reflect the distinctive features of Islamic credit, which only funds transactions related to a tangible underlying asset rather than speculative activities, thereby boosting growth rather than causing higher inflation (Kammer et al. 2015; Khan, 2010; Caporale and Helmi, 2016).

As for output growth, it appears that in the high growth regime most of its variation is driven by conventional and Islamic credit changes: the contribution of the former ( 7.949 percent) is higher than that of the latter (3.598 percent) over a 15-month forecast horizon. However, in the low growth regime their relative importance is reversed: Islamic and conventional credit changes account for 12.209 and 4.631 of the variance respectively over the same forecast horizon. The sizeable contribution of Islamic credit changes to output growth in the low growth regime could be attributed to the Islamic banks' business model and business ethics, which enhance economic growth (Adeola, 2007). Specifically, the PLS paradigm and assetbased Islamic banking make these institutions less vulnerable and more stable during financial crises; for instance, their assets and credit were double those of conventional banks during the recent financial crisis of 2007-08 in Saudi Arabia, Kuwait, UAE, Qatar, Bahrain, Jordan, Turkey and Malaysia (see Hasan and Dridi, 2010). 


\section{Conclusions}

This paper has examined the bank lending channel of monetary transmission in Malaysia, a country with a dual banking system including both Islamic and conventional banks, over the period 1994:01-2015:06. It contributes to the existing literature by using a two-regime TVAR model allowing for nonlinearities and showing that this channel in Malaysia is statedependent. In particular, the results indicate that Islamic credit changes are less responsive than conventional credit ones to interest rate shocks in both the high and low growth regimes. By contrast, the relative importance of Islamic credit changes in driving output growth is much greater in the low growth regime, their effects being positive.

These findings are broadly consistent with the existing evidence on the state-dependence of the transmission channels of monetary policy in developed economies. Moreover, they can be interpreted in terms of the distinctive features of Islamic banks, which operate according to the principles of Islamic finance, and therefore charge the ex-post PLS rate instead of conventional interest rates, and only finance projects directly linked to real economic activities (El-Gamal, 2006; Berg and Kim, 2014). Given the evidence suggesting that Islamic credit boosts growth during low growth periods, policy-makers should take into account the Islamic bank lending channel in the design of monetary policy in economies with a dual (Islamic and conventional) banking system at such times. Policies aimed at improving the institutional structure and the efficiency of Islamic banks might also be appropriate, with a view to making the transmission of monetary policy more effective in countries such as Malaysia. 


\section{References}

Abedifar, P., Molyneux, P. and Tarazi, A. (2013) 'Risk in Islamic banking', Review of Finance, 17(6), 2035-2096.

Adeola, H. (2007) 'The Role of Islamic Banking in Economic Development in Emerging

Markets' A presentation at the Islamic forum business. Lagos

Ahmad, A.H. and Pentecost, E.J. (2012) 'Identifying aggregate supply and demand shocks in small open economies: Empirical evidence from African countries', International Review of Economics \& Finance, 21(1), 272-291.

Ariff, M., (1988) 'Islamic Banking', Asian-Pacific Economic Literature, 2(2), 48-64.

Askari, H. (2012) 'Islamic finance, risk-sharing, and international financial stability', Yale Journal of International Affair, 7(1), 1-8.

Atanasova, C. (2003) 'Credit market imperfections and business cycle dynamics: A nonlinear approach', Studies in Nonlinear Dynamics \& Econometrics, 7(4).

Baele, L., Farooq, M. and Ongena, S. (2014) 'Of religion and redemption: Evidence from default on Islamic loans', Journal of Banking \& Finance, 44,141-159.

Balke, N. S. (2000) 'Credit and economic activity: credit regimes and nonlinear propagation of shocks', Review of Economics and Statistics, 82(2), 344-349.

Beck, T., Demirgüç-Kunt, A. and Merrouche, O. (2013) 'Islamic vs. conventional banking: Business model, efficiency and stability', Journal of Banking \& Finance, 37(2), 433-447.

Berg, N. and Kim, J. (2014) 'Prohibition of Riba and Gharar: A signaling and screening explanation?', Journal of Economic Behavior \& Organization, 103, S146-S159.

Bernanke, B., Blinder, A., (1992) 'The Federal funds rate and the channels of monetary transmission', The American Economic Review 82, 901-921.

Bernanke, B.S. and Gertler, M. (1995) 'Inside the black box: the credit channel of monetary policy transmission', Journal of Economic Perspectives, 9(4), 27-48. 
Brunner, K. and Meltzer, A.H. (1988) 'Money and Credit in the Monetary Transmission Process', The American Economic Review, 78(2), Papers and Proceedings of the OneHundredth Annual Meeting of the American Economic Association), 446-451.

Calza A. and Sousa J. (2006) 'Output and Inflation Responses to Credit Shocks: Are There Threshold Effects in the Euro Area? 'Studies in Nonlinear Dynamics \& Econometrics, 10 (2), $1-21$.

Çatık, A.N. and Martin, C. (2012) 'Macroeconomic transitions and the transmission mechanism: Evidence from Turkey', Economic Modelling, 29(4), 1440-1449.

Çatık, A.N. and Karaçuka, M. (2012) 'A comparative analysis of alternative univariate time series models in forecasting Turkish inflation', Journal of Business Economics and Management, 13(2), 275-293.

Çevik, S. and Charap, J. (2011) 'Behavior of Conventional and Islamic Bank Deposit Returns in Malaysia and Turkey', IMF Working Papers, 11(156), pp. 1.23

Chong, B.S. and Liu, M. (2009) 'Islamic banking: interest-free or interest-based?', PacificBasin Finance Journal, 17(1), 125-144.

Cihák, M. and Hesse, H. (2010) 'Islamic Banks and Financial Stability: An Empirical Analysis', Journal of Financial Services Research, 38(2-3), 95-113.

Caporale, G. M. and Helmi, M. H. (2016) 'Islamic Banking, Credit and Economic Growth: Some Empirical Evidence', DIW Berlin, German Institute for Economic Research. No. 1541. Available at $\quad$ SSRN: $\underline{\text { http://ssrn.com/abstract=2714816 }}$ or http://dx.doi.org/10.2139/ssrn.2714816

Di Mauro, F., Caristi, P., Couderc, S., Di Maria, A., Ho, L., Kaur Grewal, B., Masciantonio, S., Ongena, S. \& Zaheer, S. (2013) 'Islamic finance in Europe', Occasional Paper Series No. 146. European Central Bank.

El-Gamal, M.A. (2006) 'Islamic finance: Law, economics, and practice', Cambridge University Press, New York.

Ergeç, E.H. and Arslan, B.G. (2013) 'Impact of interest rates on Islamic and conventional banks: the case of Turkey', Applied Economics, 45(17), 2381-2388. 
Ernst and Young (2014) 'World Islamic Bank in Competitiveness 2013-2014 UK', Ernst \& Young Global Limited.

Ernst and Young (2016) 'World Islamic Bank in Competitiveness 2016 UK', Ernst \& Young Global Limited.

Fungácová, Z., Solanko, L. and Weill, L. (2014) 'Does competition influence the bank lending channel in the euro area?', Journal of Banking \& Finance, 49, 356-366.

Gan, P.T., and Yu, H. (2009) 'Optimal Islamic monetary policy rule for Malaysia: The Svensson's approach', International Research Journal of Finance and Economics, 30, 165176.

Ghassan, H., Fachin, S., and Guendouz, A. (2013) 'Financial Stability of Islamic and Conventional Banks in Saudi Arabia: a Time Series Analysis' (No. 2013/1). Centre for Empirical Economics and Econometrics, Department of Statistics," Sapienza" University of Rome.

Gordon, D. B., and Leeper, E. M. (1994) 'The dynamic impacts of monetary policy: an exercise in tentative identification', Journal of Political Economy, 1228-1247.

Gulzar, R. and Masih, A. (2015) 'Islamic banking: 40 years later, still interest-based? Evidence from Malaysia', MPRA Paper, University Library of Munich, Germany. Available at http://EconPapers.repec.org/RePEc:pra:mprapa:65840.

Haron, S., Ahmad, N. and Planisek, S.L. (1994) 'Bank patronage factors of Muslim and nonMuslim customers', International Journal of Bank Marketing, 12(1), 32-40.

Hasan, M. and Dridi, J., (2010) 'The effects of the global crisis on Islamic and conventional banks: a comparative study' IMF Working Paper 10(201).

Hassan, M. K. (2006) 'The X-efficiency in Islamic banks', Islamic Economic Studies, 13(2), 49-78.

International Monetary Fund. Monetary and Capital Markets Department, (2014). IMF Staff Country Reports: Malaysia - Financial Sector Assessment Program Monetary Liquidity Frameworks-Technical Note. USA: International Monetary Fund. doi: http://dx.doi.org/10.5089/9781484352243.002 
Iqbal, M. (2001) 'Islamic banking and finance: current developments in theory and practice', Leicester, UK: Islamic Foundation.

Kammer, M.A., Norat, M.M., Pinon, M.M., Prasad, A., Towe, M.C.M. \& Zeidane, M.Z. (2015) 'Islamic finance: opportunities, challenges, and policy options', IMF Staff Papers 15(5), 1-38.

Kashyap, A.K. and Stein, J.C. (2000) 'What do a million observations on banks say about the transmission of monetary policy?', The American Economic Review, 407-428.

Kashyap, A.K. and Stein, J.C. (1995) 'The impact of monetary policy on bank balance sheets', 42, 151-195.

Kashyap, A. K., \& Stein, J. C. (1995) 'The impact of monetary policy on bank balance sheets' In Carnegie-Rochester Conference Series on Public Policy (42), 151-195, North-Holland.

Kassim, S. H., Majid, M. S. A., and Yusof, R. M. (2009) 'Impact of monetary policy shocks on the conventional and islamic banks in a dual banking system: Evidence from Malaysia', Journal of Economic Cooperation and Development, 30(1), 41-58.

Kassim, S.H. and Manap, T.A.A. (2008) 'The information content of the Islamic interbank money market rate in Malaysia', International Journal of Islamic and Middle Eastern Finance and Management, 1(4), 304-312.

Kettell, B. (2010) Islamic finance in a nutshell: a guide for non-specialists. John Wiley \& Sons.

Khan, M.S. and Mirakhor, A. (1989) 'The financial system and monetary policy in an Islamic economy', Islamic Economics, 1(1), 39-58.

Khan, F. (2010) 'How 'Islamic' is Islamic banking?', Journal of Economic Behavior \& Organization, 76(3), 805-820.

Malaysia, B.N. (2012) 'Bank Negara Malaysia Annual Report 2011', Kuala Lumpur: Bank Negara Malaysia, March. Available at:

http://www.bnm.gov.my/index.php?ch=en_publication_catalogue\&pg=en_publication_bnma $\underline{\mathrm{r} \& \mathrm{ac}=89 \& \mathrm{yr}=2011}$ 
Malaysia, B.N. (2015) 'Bank Negara Malaysia Annual Report 2014', Kuala Lumpur: Bank Negara Malaysia, March. Available at:

http://www.bnm.gov.my/index.php? ch=en_publication_catalogue\&pg=en_publication_bnma $\underline{\mathrm{r} \& \mathrm{eId}=\text { box } 2 \& \text { lang }=\text { en } \& \mathrm{yr}=2014}$

Mishra, P., Montiel, P. J., \& Spilimbergo, A. (2012). Monetary transmission in low-income countries: Effectiveness and policy implications, IMF Economic Review, 60(2), 270-302.

Lee, J. and Strazicich, M.C. (2003) 'Minimum Lagrange multiplier unit root test with two structural breaks', Review of Economics and Statistics, 85(4), 1082-1089.

Peersman, G. and and Smets, F. (2001) 'The monetary transmission mechanism in the euro area: more evidence from VAR analysis', European Central Bank, Working Paper, 91.

Peersman G, Smets F. (2003) 'The monetary transmission mechanism in the euro area: evidence from VAR analysis'. In Monetary Policy Transmission in the Euro Area, Angeloni I, Kashyap A, Mojon B (eds).Cambridge University Press: Cambridge, UK, 36-55.

Phillips, P.C. and Perron, P. (1988) 'Testing for a unit root in time series regression', Biometrika, 75(2), 335-346.

Rosly, S.A. (1999) 'Al-Bay'Bithaman Ajil financing: impacts on Islamic banking performance', Thunderbird International Business Review, 41(4-5), 461-480.

Said, D. (2012) 'Efficiency in Islamic Banking during a Financial Crisis-an Empirical Analysis of Forty-Seven Banks', Journal of Applied Finance \& Banking, 2(3), 163-197.

Siddiqi, M.N. (1999) 'Islamic finance and beyond: premises and promises of Islamic economics. 'In Proceedings of the Third Harvard University Forum on Islamic Finance, Cambridge, $M A, 49-53$.

Siddiqi, M.N. (2006) 'Islamic banking and finance in theory and practice: A Survey of state of the Art', Islamic Economic Studies, 13(2), 1-48.

Sims, C. A. (1980) 'Macroeconomics and reality', Econometrica, 1-48.

Sukmana, R. and Kassim, S.H. (2010) 'Roles of the Islamic banks in the monetary transmission process in Malaysia', International Journal of Islamic and Middle Eastern Finance and Management, 3(1), 7-19. 
Tsay, R.S. (1998) 'Testing and modeling multivariate threshold models', Journal of the American Statistical Association, 93(443), 1188-1202.

Yousuf, S., Islam, M.A. and Islam, M.R. (2014) 'Islamic Banking Scenario of Bangladesh', Journal of Islamic Banking and Finance, 2(1), 23-29.

Zaher, T.S. and Hassan, M.K (2001) 'A comparative literature survey of Islamic finance and banking', Financial Markets, Institutions \& Instruments, 10(4), 155-199. 
The Appendix

Table 1. Islamic finance and market share (in billions of Malaysian ringgit).

\begin{tabular}{|c|c|c|c|c|c|c|c|}
\hline & 1994 & 1998 & 2002 & 2006 & 2010 & 2014 & $2015^{*}$ \\
\hline Total finance & 2147617.90 & 5039084.87 & 5333846.50 & 6947982.22 & 10030611.13 & 15332897.98 & 8179310.11 \\
\hline Islamic finance & 1564.00 & 87805.3 & 399125 & 897672.204 & 1807254.523 & 3690233.498 & 2127214.80 \\
\hline Share of Islamic finance & $0.073 \%$ & $1.742 \%$ & $7.482 \%$ & $12.920 \%$ & $18.017 \%$ & $24.067 \%$ & $26.01 \%$ \\
\hline
\end{tabular}

Sources: The Central Bank of Malaysia and authors calculation.

* 2015 figures are calculated based on the sum of the first two quarters of the year. 
Table 2. Lee and Strazicich unit root tests with two structural breaks.

\begin{tabular}{|c|c|c|c|c|c|c|c|c|}
\hline & \multicolumn{3}{|c|}{ Model A (Crash Model) } & \multicolumn{5}{|c|}{ Model C (Trend Shift Model) } \\
\hline & \multirow[t]{2}{*}{ Statistics } & \multicolumn{2}{|c|}{ Breaks } & \multirow[t]{2}{*}{ Statistics } & \multicolumn{3}{|c|}{ Breaks } & \multirow[b]{2}{*}{$D T_{2 t}$} \\
\hline & & $D_{1 t}$ & $D_{2 t}$ & & $D_{1 t}$ & $D_{2 t}$ & $D T_{1 t}$ & \\
\hline int $_{t}$ & -3.204 & $\begin{array}{l}\text { 1998:01 } \\
(5.793)\end{array}$ & $\begin{array}{l}\text { 2011:04 } \\
(0.351)\end{array}$ & $-5.846^{*}$ & $\begin{array}{l}1997: 06 \\
(9.101)\end{array}$ & $\begin{array}{l}2000: 07 \\
(0.385)\end{array}$ & $\begin{array}{l}1997: 06 \\
(-5.971)\end{array}$ & $\begin{array}{l}2000: 07 \\
(5.699)\end{array}$ \\
\hline$\Delta i n t_{t}$ & $-11.748^{* * *}$ & $\begin{array}{l}1998: 4 \\
(-0.537)\end{array}$ & $\begin{array}{l}2005: 10 \\
(0.251)\end{array}$ & $-10.927^{* * *}$ & $\begin{array}{l}1996: 10 \\
(1.064)\end{array}$ & $\begin{array}{l}1999: 07 \\
(0.033)\end{array}$ & $\begin{array}{l}1996: 10 \\
(-1.079)\end{array}$ & $\begin{array}{l}\text { 1999:07 } \\
(4.254)\end{array}$ \\
\hline lccre $_{t}$ & -3.170 & $\begin{array}{l}\text { 1998:12 } \\
(1.047)\end{array}$ & $\begin{array}{l}2008: 04 \\
(0.201)\end{array}$ & -2.780 & $\begin{array}{l}1997: 07 \\
(2.921)\end{array}$ & $\begin{array}{l}2003: 03 \\
(-0.198)\end{array}$ & $\begin{array}{l}1997: 07 \\
(-10.121)\end{array}$ & $\begin{array}{l}2003: 03 \\
(4.463)\end{array}$ \\
\hline$\Delta$ lccre $_{t}$ & -2.697 & $\begin{array}{l}1999: 11 \\
(-1.872)\end{array}$ & $\begin{array}{l}2008: 10 \\
(-2.403)\end{array}$ & $-6.155^{* *}$ & $\begin{array}{l}1997: 04 \\
(2.912)\end{array}$ & $\begin{array}{l}2007: 07 \\
(-2.313)\end{array}$ & $\begin{array}{l}1997: 04 \\
(-5.462)\end{array}$ & $\begin{array}{l}2007: 07 \\
(5.732)\end{array}$ \\
\hline$l c p i_{t}$ & -1.865 & $\begin{array}{l}2006: 03 \\
(-1.736)\end{array}$ & $\begin{array}{l}2008: 10 \\
(-2.298)\end{array}$ & -4.087 & $\begin{array}{l}1999: 11 \\
(3.009)\end{array}$ & $\begin{array}{l}2006: 02 \\
(4.362)\end{array}$ & $\begin{array}{l}1999: 11 \\
(-4.586)\end{array}$ & $\begin{array}{l}2006: 02 \\
(3.202)\end{array}$ \\
\hline$\Delta l c p i_{t}$ & $-5.612^{* * *}$ & $\begin{array}{l}1999: 05 \\
(-0.750)\end{array}$ & $\begin{array}{l}2009: 02 \\
(-0.607)\end{array}$ & $-9.206^{* * *}$ & $\begin{array}{l}2008: 05 \\
(13.381)\end{array}$ & $\begin{array}{l}2010: 05 \\
(-1.424)\end{array}$ & $\begin{array}{l}2008: 05 \\
(-9.327)\end{array}$ & $\begin{array}{l}2010: 05 \\
(9.364)\end{array}$ \\
\hline $\operatorname{lner}_{t}$ & -1.886 & $\begin{array}{l}1998: 08 \\
(-4.336)\end{array}$ & $\begin{array}{l}2007: 09 \\
(-1.201)\end{array}$ & -5.222 & $\begin{array}{l}1998: 03 \\
(-3.369)\end{array}$ & $\begin{array}{l}2010: 06 \\
(0.488)\end{array}$ & $\begin{array}{l}1998: 03 \\
(3.808)\end{array}$ & $\begin{array}{l}2010: 06 \\
(-3.736)\end{array}$ \\
\hline$\Delta \operatorname{lner}_{t}$ & $-4.404^{* *}$ & $\begin{array}{l}1997: 09 \\
(-4.596)\end{array}$ & $\begin{array}{l}1998: 01 \\
(-7.314)\end{array}$ & $-5.441 *$ & $\begin{array}{l}1997: 08 \\
(-0.454)\end{array}$ & $\begin{array}{l}1998: 10 \\
(-3.041)\end{array}$ & $\begin{array}{l}1997: 08 \\
(-5.122)\end{array}$ & $\begin{array}{l}1998: 10 \\
(5.483)\end{array}$ \\
\hline licre $_{t}$ & 0.275 & $\begin{array}{l}1997: 04 \\
(4.538)\end{array}$ & $\begin{array}{l}1999: 04 \\
(1.627)\end{array}$ & -2.918 & $\begin{array}{l}1997: 11 \\
(1.230)\end{array}$ & $\begin{array}{l}2002: 05 \\
(0.390)\end{array}$ & $\begin{array}{l}1997: 11 \\
(-6.646)\end{array}$ & $\begin{array}{l}2002: 05 \\
(0.533)\end{array}$ \\
\hline$\Delta$ licre $_{t}$ & $-5.510^{* * *}$ & $\begin{array}{l}1998: 02 \\
(-1.850)\end{array}$ & $\begin{array}{l}2003: 08 \\
(-0.761)\end{array}$ & $-7.787 * * *$ & $\begin{array}{l}1997: 04 \\
(8.146)\end{array}$ & $\begin{array}{l}1999: 12 \\
(-1.216)\end{array}$ & $\begin{array}{l}1997: 04 \\
(-6.648)\end{array}$ & $\begin{array}{l}1999: 12 \\
(6.491)\end{array}$ \\
\hline $\operatorname{lip}_{t}$ & -1.454 & $\begin{array}{l}2006: 09 \\
(-0.209)\end{array}$ & $\begin{array}{l}2008: 09 \\
(-0.351)\end{array}$ & -4.127 & $\begin{array}{l}1998: 03 \\
(-1.593)\end{array}$ & $\begin{array}{l}2008: 08 \\
(-5.123)\end{array}$ & $\begin{array}{l}1998: 03 \\
(-2.413)\end{array}$ & $\begin{array}{l}2008: 08 \\
(-5.242)\end{array}$ \\
\hline$\Delta l i p_{t}$ & $-5.375^{* * *}$ & $\begin{array}{l}2002: 06 \\
(1.113)\end{array}$ & $\begin{array}{l}\text { 2010:02 } \\
(1.748)\end{array}$ & $-6.502 * * *$ & $\begin{array}{l}1997: 12 \\
(-10.152)\end{array}$ & $\begin{array}{l}2000: 11 \\
(1.677)\end{array}$ & $\begin{array}{l}1997: 12 \\
(5.780)\end{array}$ & $\begin{array}{l}2000: 11 \\
(-6.384)\end{array}$ \\
\hline $\operatorname{lm} 2_{t}$ & -2.684 & $\begin{array}{l}1998: 03 \\
(-1.377)\end{array}$ & $\begin{array}{l}2003: 11 \\
(-2.484)\end{array}$ & -4.060 & $\begin{array}{l}2000: 12 \\
(-0.117)\end{array}$ & $\begin{array}{l}2006: 04 \\
(-0.899)\end{array}$ & $\begin{array}{l}2000: 12 \\
(-3.819)\end{array}$ & $\begin{array}{l}2006: 04 \\
(2.845)\end{array}$ \\
\hline$\Delta \operatorname{lm} 2_{t}$ & $-5.166^{* * *}$ & $\begin{array}{l}2002: 12 \\
(0.649)\end{array}$ & $\begin{array}{l}2010: 04 \\
(0.356)\end{array}$ & $-8.004 * * *$ & $\begin{array}{l}1997: 11 \\
(4.908)\end{array}$ & $\begin{array}{l}2005: 06 \\
(-5.428)\end{array}$ & $\begin{array}{l}1997: 11 \\
(-7.389)\end{array}$ & $\begin{array}{l}2005: 06 \\
(7.781)\end{array}$ \\
\hline ltcre $_{t}$ & -3.200 & $\begin{array}{l}1999: 04 \\
(2.734)\end{array}$ & $\begin{array}{l}2008: 06 \\
(-0.668)\end{array}$ & -2.914 & $\begin{array}{l}1998: 10 \\
(0.975)\end{array}$ & $\begin{array}{l}2011: 07 \\
(0.351)\end{array}$ & $\begin{array}{l}1998: 10 \\
(-7.742)\end{array}$ & $\begin{array}{l}2011: 07 \\
(3.472)\end{array}$ \\
\hline$\Delta$ ltcre $_{t}$ & $-6.542^{* * *}$ & $\begin{array}{l}\text { 1998:01 } \\
(-3.201)\end{array}$ & $\begin{array}{l}2007: 12 \\
(-3.063)\end{array}$ & $-12.843 * * *$ & $\begin{array}{l}1997: 11 \\
(-0.358)\end{array}$ & $\begin{array}{l}2000: 03 \\
(0.388)\end{array}$ & $\begin{array}{l}1997: 11 \\
(-7.924)\end{array}$ & $\begin{array}{l}2000: 03 \\
(4.163)\end{array}$ \\
\hline$f f r_{t}$ & -2.817 & $\begin{array}{l}2001: 04 \\
(-2.494)\end{array}$ & $\begin{array}{l}2008: 01 \\
(-6.035)\end{array}$ & 4.256 & $\begin{array}{l}2002: 06 \\
(-0.005)\end{array}$ & $\begin{array}{l}2007: 12 \\
(0.206)\end{array}$ & $\begin{array}{l}2002: 06 \\
(-2.138)\end{array}$ & $\begin{array}{l}2007: 12 \\
(-5.352)\end{array}$ \\
\hline$\Delta f f r_{t}$ & $-5.421^{* * *}$ & $\begin{array}{l}1999: 05 \\
(-1.189)\end{array}$ & $\begin{array}{l}2007: 04 \\
(-0.800)\end{array}$ & $-8.810^{* * *}$ & $\begin{array}{l}2005: 08 \\
(-6.726)\end{array}$ & $\begin{array}{l}\text { 2008:09 } \\
(8.330)\end{array}$ & $\begin{array}{l}2005: 08 \\
(8.106)\end{array}$ & $\begin{array}{l}2008: 09 \\
(-8.267)\end{array}$ \\
\hline lcompri $_{t}$ & -1.828 & $\begin{array}{l}2010: 04 \\
(-3.586)\end{array}$ & $\begin{array}{l}2012: 08 \\
(1.566)\end{array}$ & -4.268 & $\begin{array}{l}2001: 12 \\
(0.391)\end{array}$ & $\begin{array}{l}2010: 04 \\
(-4.137)\end{array}$ & $\begin{array}{l}2001: 12 \\
(1.188)\end{array}$ & $\begin{array}{l}2010: 04 \\
(-0.660)\end{array}$ \\
\hline$\Delta l c o m p r i i_{t}$ & $-4.621^{* * *}$ & $\begin{array}{l}2002: 08 \\
(1.3770)\end{array}$ & $\begin{array}{l}2013: 05 \\
(-0.484)\end{array}$ & $-6.855^{* * *}$ & $\begin{array}{l}2006: 04 \\
(2.807)\end{array}$ & $\begin{array}{l}2009: 06 \\
(-2.213)\end{array}$ & $\begin{array}{l}2006: 04 \\
(-4.357)\end{array}$ & $\begin{array}{l}2009: 06 \\
(6.469)\end{array}$ \\
\hline $\operatorname{lipus}_{t}$ & -1.446 & $\begin{array}{l}2005: 08 \\
(-3.728)\end{array}$ & $\begin{array}{l}2008: 08 \\
(-7.293)\end{array}$ & -4.428 & $\begin{array}{l}1998: 06 \\
(-1.203)\end{array}$ & $\begin{array}{l}2008: 08 \\
(-6.661)\end{array}$ & $\begin{array}{l}1998: 06 \\
(-0.310)\end{array}$ & $\begin{array}{l}2008: 08 \\
(-3.206)\end{array}$ \\
\hline$\Delta \operatorname{lipus}_{t}$ & $-5.509^{* * *}$ & $\begin{array}{l}1999: 05 \\
(1.348)\end{array}$ & $\begin{array}{l}2007: 02 \\
(-0.681)\end{array}$ & $-8.568^{* * *}$ & $\begin{array}{l}2005: 08 \\
(-6.384)\end{array}$ & $\begin{array}{l}2008: 09 \\
(7.986)\end{array}$ & $\begin{array}{l}2005: 08 \\
(7.844)\end{array}$ & $\begin{array}{l}2008: 09 \\
(-8.017)\end{array}$ \\
\hline
\end{tabular}

Notes: $\Delta$ is the first difference operator. ltcre $_{t}$, lccre $_{t}$, licre $_{t}$, int $_{t}$, lcpi $_{t}$, lipi $_{t}$, lm $_{t}$, lcompri $_{t}$, ffr $_{t}$, lipus $_{t}$, and lner $_{t}$ denote respectively the $\log$ of total credit, the log of conventional credit, the log of Islamic credit, policy rate, the log of price level, the log of industrial production, the log of money supply, the log of the world commodity price index, the US federal funds rate, the log of the US industrial production index, and the log of the nominal exchange rate vis-à-vis the US dollar. The general to specific procedure is followed to find the optimum lag length, allowing for a maximum of 12 lags. The t-statistics are represented in parentheses (.). The critical values are obtained from Lee and Strazicich (2003). Model A allows for breaks in the intercept, whereas Model C allows for breaks in both the intercept and the trend. $D_{1 t}$ and $D_{2 t}$ refer to the first and second break dates, while $D T_{1 t}$ and $D T_{2 t}$ indicate the first and second break dates when allowing for the trend. ${ }^{* * *},{ }^{* *}$, and ${ }^{*}$ indicate statistical significance at the $1 \%, 5 \%$, and $10 \%$ levels, respectively. 
Table 3. Summary of descriptive statistics for the endogenous variables.

\begin{tabular}{llllllll}
\hline & \multicolumn{1}{c}{$\Delta$ ltcre $_{t}$} & \multicolumn{1}{c}{$\Delta$ sccre $_{t}$} & \multicolumn{1}{c}{$\Delta$ licre $_{t}$} & \multicolumn{1}{c}{$\Delta$ sint $_{t}$} & \multicolumn{1}{c}{$\Delta$ lcpi $_{t}$} & \multicolumn{1}{c}{$\Delta$ lipi $_{t}$} & \multicolumn{1}{c}{$\Delta \operatorname{lm} 2_{t}$} \\
\hline Maximum & 0.059 & 0.058 & 0.692 & 4.260 & 0.038 & 0.096 & 0.055 \\
Minimum & -0.019 & -0.020 & -0.024 & -5.180 & -0.011 & -0.076 & -0.019 \\
Mean & 0.008 & 0.006 & 0.034 & -0.001 & 0.002 & 0.004 & 0.009 \\
St. Deviation & 0.008 & 0.009 & 0.069 & 0.590 & 0.003 & 0.026 & 0.010 \\
Skewness & 0.964 & 0.994 & 5.584 & -1.581 & 3.205 & 0.203 & 0.556 \\
Ex. kurtosis & 7.322 & 7.145 & 42.658 & 40.598 & 32.75 & 3.722 & 4.503 \\
JB & $238.95^{* * *}$ & $225.567^{* * *}$ & $18107.1^{* * *}$ & $15185.5^{* * *}$ & $9923.7^{* * *}$ & $7.357^{* *}$ & $37.30^{* * *}$ \\
Observations & 256 & 256 & 256 & 256 & 256 & 256 & 256 \\
\hline
\end{tabular}

Notes: $\Delta$ ltcre $_{t}, \Delta$ lccre $_{t}, \Delta$ licre $_{t}, \Delta i n t_{t}, \Delta l c p i_{t}, \Delta l i p i_{t}$, and $\Delta l m 2_{t}$ denote respectively total credit changes, conventional credit changes, Islamic credit changes, policy rate changes, price level changes (inflation), industrial production growth, and money supply growth, respectively. JB is the Jarque-Bera test for normality. ${ }^{* * *}$, and ${ }^{* *}$ indicate statistical significance at the $1 \%$ and $5 \%$ levels, respectively. 
Table 4. Multivariate threshold nonlinearity tests.

\begin{tabular}{|c|c|c|c|c|c|c|c|c|c|c|c|}
\hline \multicolumn{4}{|c|}{ Model 1} & \multicolumn{4}{|c|}{ Model 2} & \multicolumn{4}{|c|}{ Model 3} \\
\hline$d$ & $m_{0}$ & $C(d)$ statistics & P-value & $\mathrm{d}$ & $m_{0}$ & $C(d)$ statistics & P-value & $d$ & $m_{0}$ & $C(d)$ statistics & $\mathrm{P}$-value \\
\hline 1 & 25 & 186.490 & 0.000 & 1 & 25 & 188.160 & 0.000 & 1 & 25 & 164.240 & 0.000 \\
\hline 1 & 50 & 174.990 & 0.000 & 1 & 50 & 176.150 & 0.000 & 1 & 50 & 157.070 & 0.000 \\
\hline 2 & 25 & 172.430 & 0.000 & 2 & 25 & 174.790 & 0.000 & 2 & 25 & 154.080 & 0.000 \\
\hline 2 & 50 & 188.660 & 0.000 & 2 & 50 & 190.040 & 0.000 & 2 & 50 & 168.210 & 0.000 \\
\hline 3 & 25 & 173.450 & 0.000 & 3 & 25 & 177.260 & 0.000 & 3 & 25 & 174.110 & 0.000 \\
\hline 3 & 50 & 188.780 & 0.000 & 3 & 50 & 194.410 & 0.000 & 3 & 50 & 184.250 & 0.000 \\
\hline 4 & 25 & 121.780 & 0.033 & 4 & 25 & 125.550 & 0.020 & 4 & 25 & 106.660 & 0.195 \\
\hline 4 & 50 & 120.120 & 0.042 & 4 & 50 & 123.730 & 0.025 & 4 & 50 & 105.140 & 0.224 \\
\hline 5 & 25 & 136.840 & 0.003 & 5 & 25 & 142.250 & 0.001 & 5 & 25 & 117.300 & 0.060 \\
\hline 5 & 50 & 131.730 & 0.008 & 5 & 50 & 137.170 & 0.003 & 5 & 50 & 113.370 & 0.096 \\
\hline$\gamma$ & 5.5615 & AIC & 2440.74 & $\gamma$ & 5.558 & $\mathrm{AIC}$ & 2427.456 & $\gamma$ & 5.5563 & AIC & 3312.63 \\
\hline
\end{tabular}

Notes: The AIC refers to the minimum value of Akaike Information Criterion, $C(d)$ statistics is based on the arranged regression model introduced by Tsay (1998), $d$ is the delay parameter, $m_{0}$ refers to the number of initial observations, and $\gamma$ represents the optimum values of the threshold variable, magr (the twenty-four month moving average of the IPI growth rate). 
Table 5. Variance decomposition of inflation.

\begin{tabular}{|c|c|c|c|c|c|c|c|c|c|c|c|c|c|c|c|c|c|c|c|c|}
\hline \multicolumn{7}{|c|}{$\begin{array}{c}\text { Model } 1 \\
\text { Linear VAR }\end{array}$} & \multicolumn{7}{|c|}{$\begin{array}{c}\text { Model } 2 \\
\text { Linear VAR } \\
\end{array}$} & \multicolumn{7}{|c|}{$\begin{array}{c}\text { Model } 3 \\
\text { Linear VAR } \\
\end{array}$} \\
\hline Step & S.E. & $\Delta l m 2_{t}$ & $\Delta i n t_{t}$ & $\Delta$ ltcre $_{t}$ & $\Delta l c p i_{t}$ & $\Delta \operatorname{lipi}_{t}$ & Step & S.E. & $\Delta \operatorname{lm} 2_{t}$ & $\Delta i n t_{t}$ & $\Delta_{\text {lccre }}$ & $\Delta l c p i_{t}$ & $\Delta \operatorname{lipi}_{t}$ & Step & S.E. & $\Delta \operatorname{lm} 2_{t}$ & $\Delta i n t_{t}$ & $\Delta$ licre $_{t}$ & $\Delta l c p i_{t}$ & $\Delta \operatorname{lipi}_{t}$ \\
\hline 1 & 0.342 & 0.134 & 0.639 & 1.553 & 97.675 & 0.000 & 1 & 0.341 & 0.116 & 0.638 & 1.936 & 97.310 & 0.000 & 1 & 0.346 & 0.179 & 0.885 & 0.006 & 98.930 & 0.000 \\
\hline 3 & 0.357 & 0.865 & 0.909 & 2.466 & 95.724 & 0.036 & 3 & 0.357 & 0.845 & 0.928 & 3.362 & 94.837 & 0.029 & 3 & 0.362 & 1.647 & 1.234 & 0.967 & 96.002 & 0.149 \\
\hline 6 & 0.358 & 0.984 & 0.924 & 2.554 & 95.309 & 0.230 & 6 & 0.358 & 0.970 & 0.941 & 3.425 & 94.462 & 0.203 & 6 & 0.363 & 1.790 & 1.251 & 0.964 & 95.554 & 0.442 \\
\hline 9 & 0.358 & 0.985 & 0.926 & 2.554 & 95.305 & 0.231 & 9 & 0.358 & 0.971 & 0.943 & 3.425 & 94.458 & 0.204 & 9 & 0.363 & 1.790 & 1.255 & 0.964 & 95.545 & 0.446 \\
\hline 12 & 0.358 & 0.985 & 0.926 & 2.554 & 95.305 & 0.231 & 12 & 0.358 & 0.971 & 0.943 & 3.425 & 94.458 & 0.204 & 12 & 0.363 & 1.790 & 1.255 & 0.964 & 95.545 & 0.446 \\
\hline 15 & 0.358 & 0.985 & 0.926 & 2.554 & 95.305 & 0.231 & 15 & 0.358 & 0.971 & 0.943 & 3.425 & 94.458 & 0.204 & 15 & 0.363 & 1.790 & 1.255 & 0.964 & 95.545 & 0.446 \\
\hline \multicolumn{7}{|c|}{ Upper Regime } & \multicolumn{7}{|c|}{ Upper Regime } & \multicolumn{7}{|c|}{ Upper Regime } \\
\hline Step & S.E. & $\Delta l m 2_{t}$ & $\Delta \operatorname{sint}_{t}$ & $\Delta$ ltcre $_{t}$ & $\Delta l c p i_{t}$ & $\Delta \operatorname{lipi}_{t}$ & Step & S.E. & $\Delta \operatorname{lm} 2_{t}$ & $\Delta \operatorname{sint}_{t}$ & slccre $_{t}$ & $\Delta l c p i_{t}$ & $\Delta \operatorname{lipi}_{t}$ & Step & S.E. & $\Delta \operatorname{lm} 2_{t}$ & $\Delta i n t_{t}$ & $\Delta$ licre $_{t}$ & $\Delta l c p i_{t}$ & $\Delta \operatorname{lipi}_{t}$ \\
\hline 1 & 0.277 & 3.219 & 0.299 & 0.876 & 95.606 & 0.000 & 1 & 0.276 & 2.824 & 0.321 & 1.324 & 95.531 & 0.000 & 1 & 0.220 & 7.640 & 0.024 & 1.781 & 90.556 & 0.000 \\
\hline 3 & 0.285 & 3.812 & 0.678 & 1.064 & 93.452 & 0.994 & 3 & 0.285 & 3.441 & 0.681 & 2.228 & 92.642 & 1.007 & 3 & 0.224 & 7.604 & 0.400 & 2.731 & 89.201 & 0.065 \\
\hline 6 & 0.286 & 3.840 & 0.757 & 1.173 & 92.709 & 1.521 & 6 & 0.286 & 3.468 & 0.745 & 2.330 & 91.960 & 1.498 & 6 & 0.225 & 7.591 & 0.546 & 2.751 & 88.851 & 0.260 \\
\hline 9 & 0.287 & 3.838 & 0.757 & 1.196 & 92.669 & 1.541 & 9 & 0.286 & 3.466 & 0.744 & 2.354 & 91.917 & 1.517 & 9 & 0.225 & 7.590 & 0.552 & 2.753 & 88.837 & 0.269 \\
\hline 12 & 0.287 & 3.838 & 0.757 & 1.198 & 92.666 & 1.542 & 12 & 0.286 & 3.466 & 0.744 & 2.356 & 91.914 & 1.519 & 12 & 0.225 & 7.590 & 0.552 & 2.753 & 88.836 & 0.270 \\
\hline 15 & 0.287 & 3.838 & 0.757 & 1.198 & 92.665 & 1.542 & 15 & 0.286 & 3.466 & 0.744 & 2.356 & 91.914 & 1.519 & 15 & 0.225 & 7.590 & 0.552 & 2.753 & 88.836 & 0.270 \\
\hline \multicolumn{7}{|c|}{ Lower Regime } & \multicolumn{7}{|c|}{ Lower Regime } & \multicolumn{7}{|c|}{ Lower Regime } \\
\hline Step & S.E. & $\Delta \operatorname{lm} 2_{t}$ & $\Delta i n t_{t}$ & $\Delta$ ltcre $_{t}$ & $\Delta l c p i_{t}$ & $\Delta \operatorname{lipi}_{t}$ & Step & S.E. & $\Delta \operatorname{lm} 2_{t}$ & $\Delta i n t_{t}$ & $\Delta$ lccre $_{t}$ & $\Delta l c p i_{t}$ & $\Delta \operatorname{lipi}_{t}$ & Step & S.E. & $\Delta \operatorname{lm} 2_{t}$ & $\Delta i n t_{t}$ & $\Delta$ licre $_{t}$ & $\Delta l c p i_{t}$ & $\Delta \operatorname{lipi}_{t}$ \\
\hline 1 & 0.364 & 0.643 & 0.667 & 4.268 & 94.422 & 0.000 & 1 & 0.363 & 0.715 & 0.732 & 4.741 & 93.811 & 0.000 & 1 & 0.413 & 1.589 & 1.041 & 0.919 & 96.451 & 0.000 \\
\hline 3 & 0.393 & 2.797 & 1.821 & 8.107 & 86.308 & 0.967 & 3 & 0.392 & 2.781 & 2.018 & 8.263 & 85.992 & 0.945 & 3 & 0.446 & 3.746 & 2.713 & 1.534 & 91.003 & 1.003 \\
\hline 6 & 0.394 & 2.911 & 1.896 & 8.239 & 85.879 & 1.075 & 6 & 0.394 & 2.908 & 2.078 & 8.395 & 85.598 & 1.022 & 6 & 0.449 & 3.860 & 2.857 & 1.666 & 89.992 & 1.625 \\
\hline 9 & 0.394 & 2.914 & 1.906 & 8.250 & 85.853 & 1.077 & 9 & 0.394 & 2.910 & 2.090 & 8.400 & 85.577 & 1.023 & 9 & 0.449 & 3.855 & 2.898 & 1.770 & 89.843 & 1.634 \\
\hline 12 & 0.394 & 2.914 & 1.907 & 8.251 & 85.852 & 1.077 & 12 & 0.394 & 2.910 & 2.091 & 8.400 & 85.576 & 1.023 & 12 & 0.449 & 3.854 & 2.900 & 1.792 & 89.816 & 1.639 \\
\hline 15 & 0.394 & 2.914 & 1.907 & 8.251 & 85.852 & 1.077 & 15 & 0.394 & 2.910 & 2.091 & 8.400 & 85.576 & 1.023 & 15 & 0.449 & 3.853 & 2.901 & 1.792 & 89.814 & 1.639 \\
\hline
\end{tabular}

Notes: Models 1, 2 and 3 are respectively based on the vectors $Y_{1, t}^{\prime}=\left[\Delta l m 2_{t}, \Delta\right.$ int $_{t}, \Delta$ ltcre $_{t}, \Delta$ lcpi $_{t}, \Delta$ lipi $\left._{t}\right], Y_{2, t}^{\prime}=\left[\Delta\right.$ lm2 $_{t}, \Delta$ int $_{t}, \Delta l c c r e_{t}, \Delta l c p i_{t}, \Delta$ lipi $\left._{t}\right]{\text { and } Y_{3, t}^{\prime}=}^{\prime}$

$\left[\Delta l m 2_{t}, \Delta i n t_{t}, \Delta\right.$ licre $_{t}, \Delta l c p i_{t}, \Delta$ lipi $\left._{t}\right]$, respectively. 
Table 6. Variance decomposition of output.

\begin{tabular}{|c|c|c|c|c|c|c|c|c|c|c|c|c|c|c|c|c|c|c|c|c|}
\hline \multicolumn{7}{|c|}{$\begin{array}{c}\text { Model } 1 \\
\text { Linear VAR }\end{array}$} & \multicolumn{7}{|c|}{$\begin{array}{c}\text { Mode } 2 \\
\text { Linear VAR } \\
\end{array}$} & \multicolumn{7}{|c|}{$\begin{array}{c}\text { Mode } 3 \\
\text { Linear VAR } \\
\end{array}$} \\
\hline Step & S.E. & $\Delta l m 2_{t}$ & $\Delta i n t_{t}$ & $\Delta$ ltcre $_{t}$ & $\Delta l c p i_{t}$ & $\Delta \operatorname{lipi}_{t}$ & Step & S.E. & $\Delta \operatorname{lm} 2_{t}$ & $\Delta i n t_{t}$ & $\Delta$ lccre $_{t}$ & $\Delta l c p i_{t}$ & $\Delta \operatorname{lipi}_{t}$ & Step & S.E. & $\Delta \operatorname{lm} 2_{t}$ & $\Delta i n t_{t}$ & sicre $_{t}$ & $\Delta l c p i_{t}$ & $\Delta \operatorname{lipi}_{t}$ \\
\hline 1 & 0.750 & 1.053 & 0.092 & 0.020 & 0.062 & 98.773 & 1 & 0.750 & 0.980 & 0.128 & 0.153 & 0.076 & 98.662 & 1 & 0.791 & 0.794 & 0.227 & 1.687 & 0.013 & 97.278 \\
\hline 3 & 0.960 & 0.782 & 3.357 & 0.326 & 0.232 & 95.302 & 3 & 0.962 & 0.741 & 3.653 & 0.242 & 0.280 & 95.084 & 3 & 1.007 & 0.766 & 4.372 & 1.708 & 0.464 & 92.690 \\
\hline 6 & 0.973 & 0.787 & 3.671 & 1.024 & 0.621 & 93.897 & 6 & 0.974 & 0.751 & 4.029 & 0.641 & 0.658 & 93.921 & 6 & 1.026 & 0.746 & 4.966 & 1.681 & 1.221 & 91.386 \\
\hline 9 & 0.973 & 0.791 & 3.670 & 1.071 & 0.643 & 93.824 & 9 & 0.974 & 0.754 & 4.029 & 0.677 & 0.675 & 93.865 & 9 & 1.027 & 0.753 & 4.983 & 1.686 & 1.255 & 91.323 \\
\hline 12 & 0.973 & 0.792 & 3.670 & 1.072 & 0.643 & 93.823 & 12 & 0.974 & 0.754 & 4.029 & 0.677 & 0.675 & 93.865 & 12 & 1.027 & 0.753 & 4.983 & 1.686 & 1.255 & 91.323 \\
\hline 15 & 0.973 & 0.792 & 3.670 & 1.072 & 0.643 & 93.823 & 15 & 0.974 & 0.754 & 4.029 & 0.677 & 0.675 & 93.865 & 15 & 1.027 & 0.753 & 4.983 & 1.686 & 1.255 & 91.323 \\
\hline \multicolumn{7}{|c|}{ Upper Regime } & \multicolumn{7}{|c|}{ Upper Regime } & \multicolumn{7}{|c|}{ Upper Regime } \\
\hline Step & S.E. & $\Delta \operatorname{lm} 2_{t}$ & $\Delta i n t_{t}$ & $\Delta$ ltcre $_{t}$ & $\Delta l c p i_{t}$ & $\Delta \operatorname{lipi}_{t}$ & Step & S.E. & $\Delta \operatorname{lm} 2_{t}$ & $\Delta i n t_{t}$ & $\Delta$ lccre $_{t}$ & $\Delta l c p i_{t}$ & $\Delta \operatorname{lipi}_{t}$ & Step & S.E. & $\Delta \operatorname{lm} 2_{t}$ & $\Delta i n t_{t}$ & slicre $_{t}$ & $\Delta l c p i_{t}$ & $\Delta \operatorname{lipi}_{t}$ \\
\hline 1 & 0.583 & 6.911 & 0.890 & 0.356 & 0.011 & 91.832 & 1 & 0.584 & 6.853 & 1.144 & 0.178 & 0.004 & 91.821 & 1 & 0.596 & 2.683 & 0.268 & 0.144 & 0.594 & 96.311 \\
\hline 3 & 0.719 & 4.650 & 0.865 & 3.873 & 1.603 & 89.009 & 3 & 0.719 & 4.678 & 0.952 & 3.907 & 1.409 & 89.054 & 3 & 0.740 & 3.299 & 1.204 & 2.258 & 2.713 & 90.525 \\
\hline 6 & 0.750 & 4.299 & 0.853 & 7.265 & 1.851 & 85.732 & 6 & 0.751 & 4.328 & 0.935 & 7.549 & 1.637 & 85.551 & 6 & 0.774 & 3.271 & 1.380 & 3.483 & 3.465 & 88.401 \\
\hline 9 & 0.753 & 4.269 & 0.848 & 7.582 & 1.902 & 85.399 & 9 & 0.754 & 4.295 & 0.928 & 7.921 & 1.679 & 85.177 & 9 & 0.777 & 3.280 & 1.402 & 3.592 & 3.536 & 88.190 \\
\hline 12 & 0.753 & 4.267 & 0.847 & 7.603 & 1.906 & 85.377 & 12 & 0.754 & 4.293 & 0.927 & 7.947 & 1.682 & 85.151 & 12 & 0.777 & 3.281 & 1.403 & 3.598 & 3.540 & 88.178 \\
\hline 15 & 0.753 & 4.267 & 0.847 & 7.605 & 1.906 & 85.375 & 15 & 0.754 & 4.293 & 0.927 & 7.949 & 1.683 & 85.149 & 15 & 0.777 & 3.281 & 1.403 & 3.598 & 3.541 & 88.177 \\
\hline \multicolumn{7}{|c|}{ Lower Regime } & \multicolumn{7}{|c|}{ Lower Regime } & \multicolumn{7}{|c|}{ Lower Regime } \\
\hline Step & S.E. & $\Delta \operatorname{lm} 2_{t}$ & $\Delta i n t_{t}$ & $\Delta$ ltcre $_{t}$ & $\Delta l c p i_{t}$ & $\Delta l i p i_{t}$ & Step & S.E. & $\Delta \operatorname{lm} 2_{t}$ & $\Delta i n t_{t}$ & $\Delta$ lccre $_{t}$ & $\Delta l c p i_{t}$ & $\Delta l i p i_{t}$ & Step & S.E. & $\Delta \operatorname{lm} 2_{t}$ & $\Delta i n t_{t}$ & $\Delta$ licre $_{t}$ & $\Delta l c p i_{t}$ & $\Delta \operatorname{lipi}_{t}$ \\
\hline 1 & 0.776 & 0.050 & 3.869 & 5.056 & 2.971 & 88.053 & 1 & 0.776 & 0.077 & 3.998 & 5.531 & 3.058 & 87.336 & 1 & 0.791 & 0.055 & 4.080 & 1.012 & 1.875 & 92.978 \\
\hline 3 & 0.982 & 0.379 & 14.057 & 4.026 & 8.231 & 73.308 & 3 & 0.982 & 0.425 & 14.733 & 4.262 & 7.674 & 72.906 & 3 & 0.998 & 0.354 & 10.458 & 5.003 & 7.432 & 76.752 \\
\hline 6 & 1.006 & 0.624 & 16.300 & 4.653 & 8.373 & 70.050 & 6 & 1.007 & 0.677 & 17.477 & 4.459 & 7.857 & 69.530 & 6 & 1.048 & 0.692 & 10.407 & 11.260 & 7.543 & 70.097 \\
\hline 9 & 1.008 & 0.637 & 16.282 & 4.854 & 8.474 & 69.753 & 9 & 1.009 & 0.689 & 17.470 & 4.629 & 7.965 & 69.247 & 9 & 1.056 & 0.690 & 10.390 & 12.204 & 7.551 & 69.165 \\
\hline 12 & 1.008 & 0.640 & 16.281 & 4.855 & 8.476 & 69.748 & 12 & 1.009 & 0.692 & 17.469 & 4.631 & 7.967 & 69.242 & 12 & 1.057 & 0.691 & 10.438 & 12.202 & 7.554 & 69.116 \\
\hline 15 & 1.008 & 0.640 & 16.281 & 4.855 & 8.476 & 69.748 & 15 & 1.009 & 0.692 & 17.469 & 4.631 & 7.967 & 69.242 & 15 & 1.057 & 0.691 & 10.437 & 12.209 & 7.556 & 69.107 \\
\hline
\end{tabular}

Notes: Models 1, 2 and 3 are respectively based on the vectors $Y_{1, t}^{\prime}=\left[\Delta l m 2_{t}, \Delta i n t_{t}, \Delta l t c r e_{t}, \Delta l c p i_{t} \Delta l i p i_{t}\right], Y_{2, t}^{\prime}=\left[\Delta \operatorname{lm}_{t}, \Delta i n t_{t}, \Delta l c c r e_{t}, \Delta l c p i_{t} \Delta l i p i_{t}\right]$ and $Y_{3, t}^{\prime}=$

$\left[\Delta l m 2_{t}, \Delta i n t_{t}, \Delta \operatorname{licre}_{t}, \Delta l c p i_{t} \Delta \operatorname{lipi}_{t}\right]$, respectively. 
Figure 1. Regime classifications.

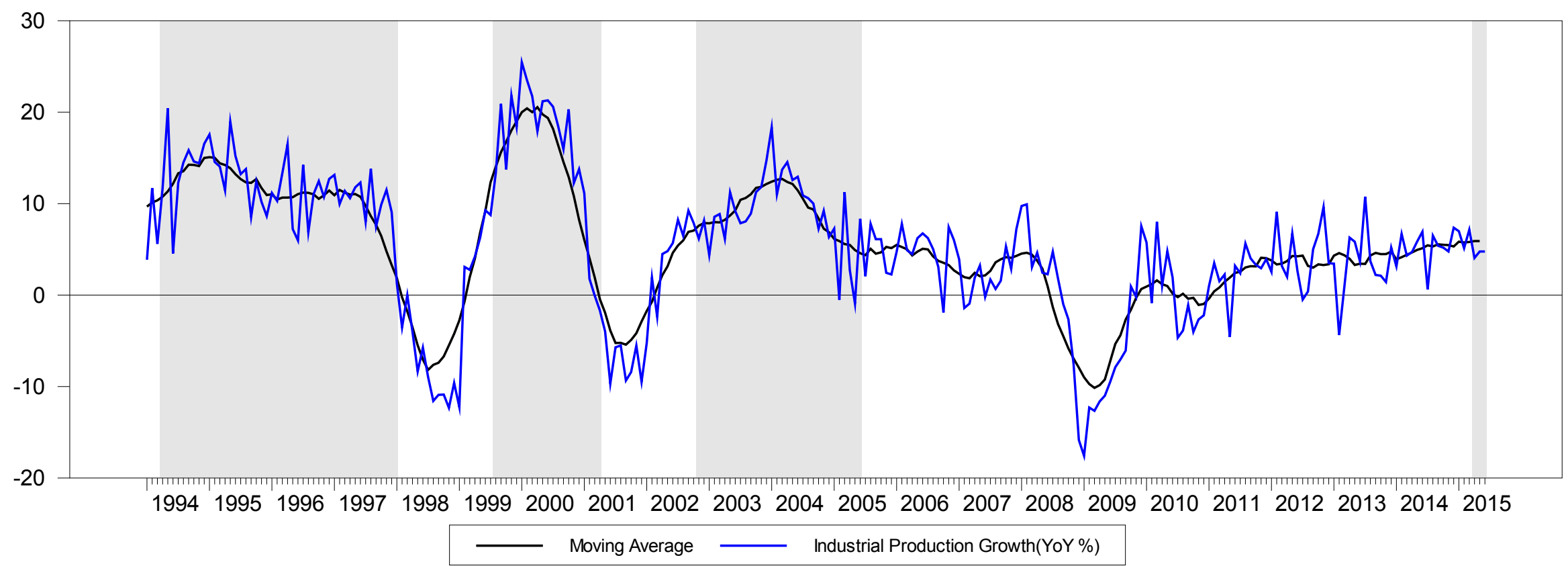

Note: Upper regime where $\gamma \geq 5.5615$, is represented by the shaded areas obtained from the TVAR, specification of model 1 . 
Figure 2. Responses to interest rate changes shocks.
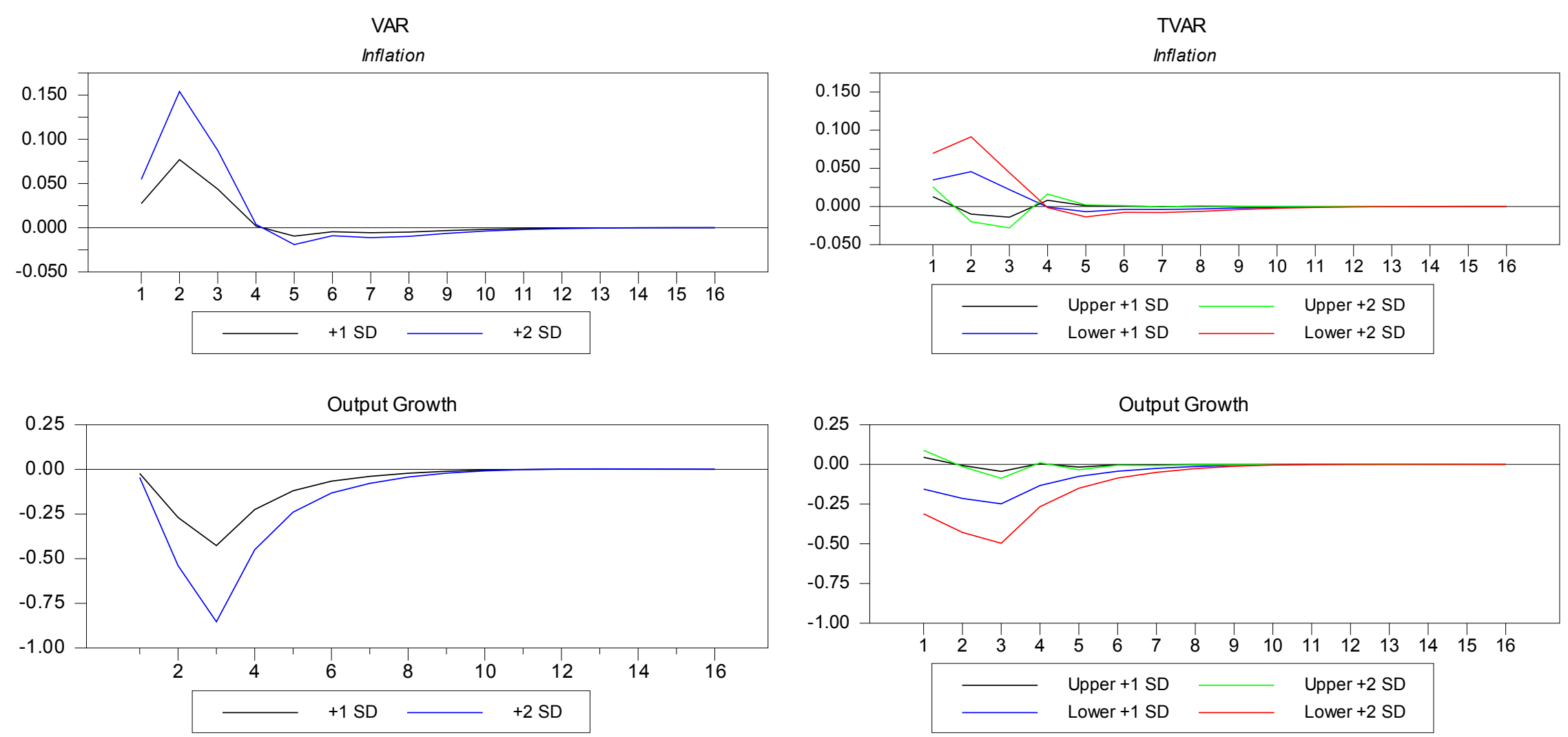

Note: The figures are obtained from model 1. 
Figure 3. Responses to negative money supply changes shocks.
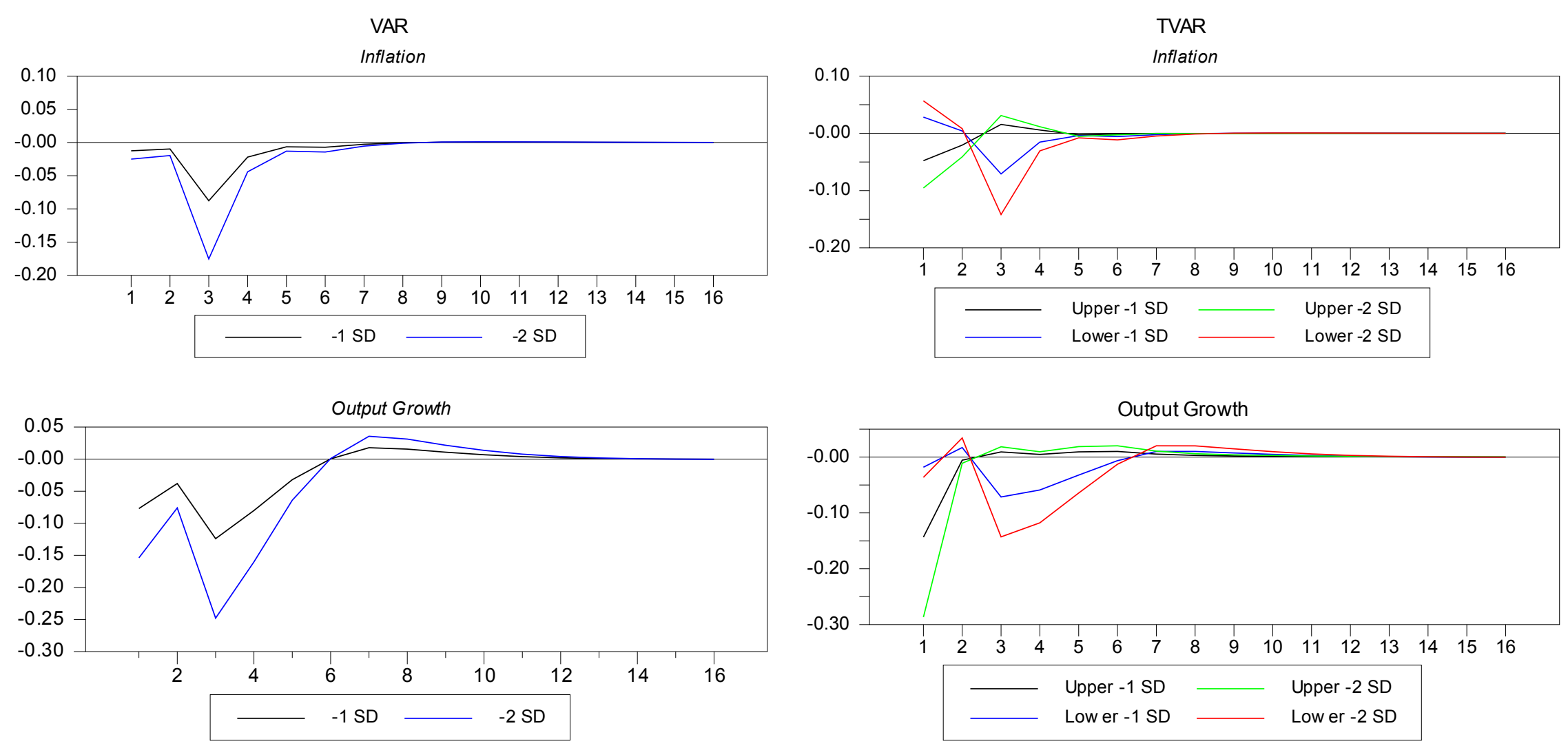

Note: The figures are obtained from model 1. 
Figure 4. Responses of output growth to credit changes shocks.

Responses of Output Growth to Total Credit Changes Shocks
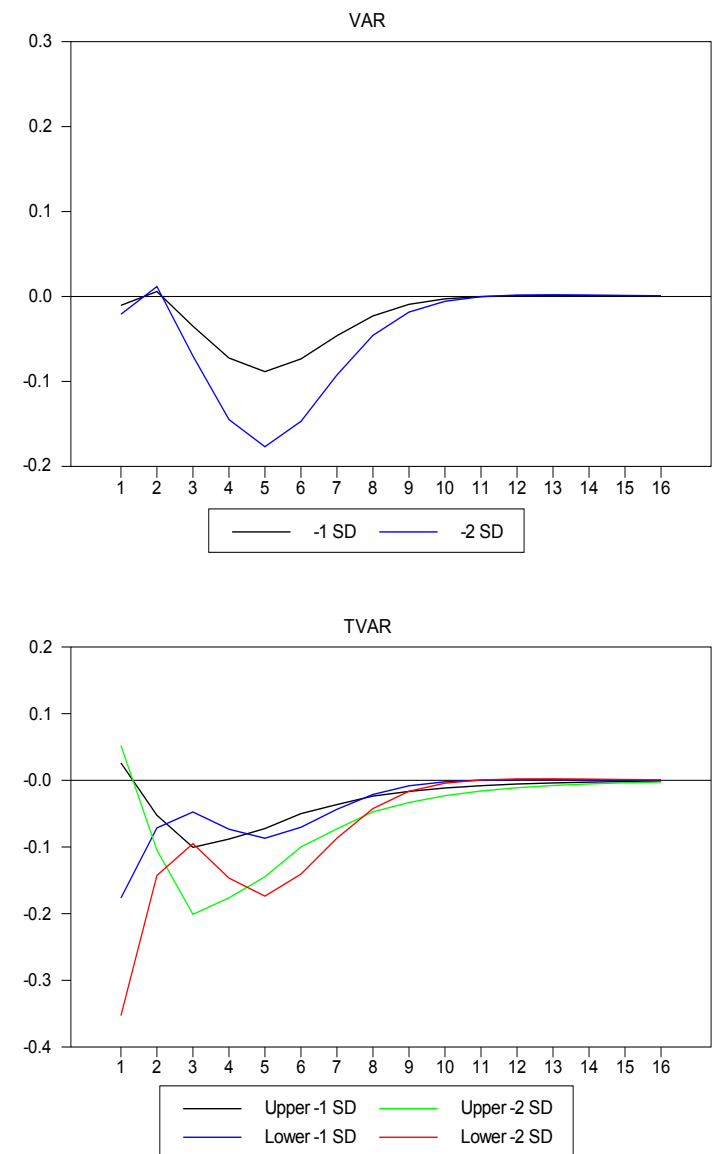

Responses of Output Growth to Commercial Credit Changes Shocks
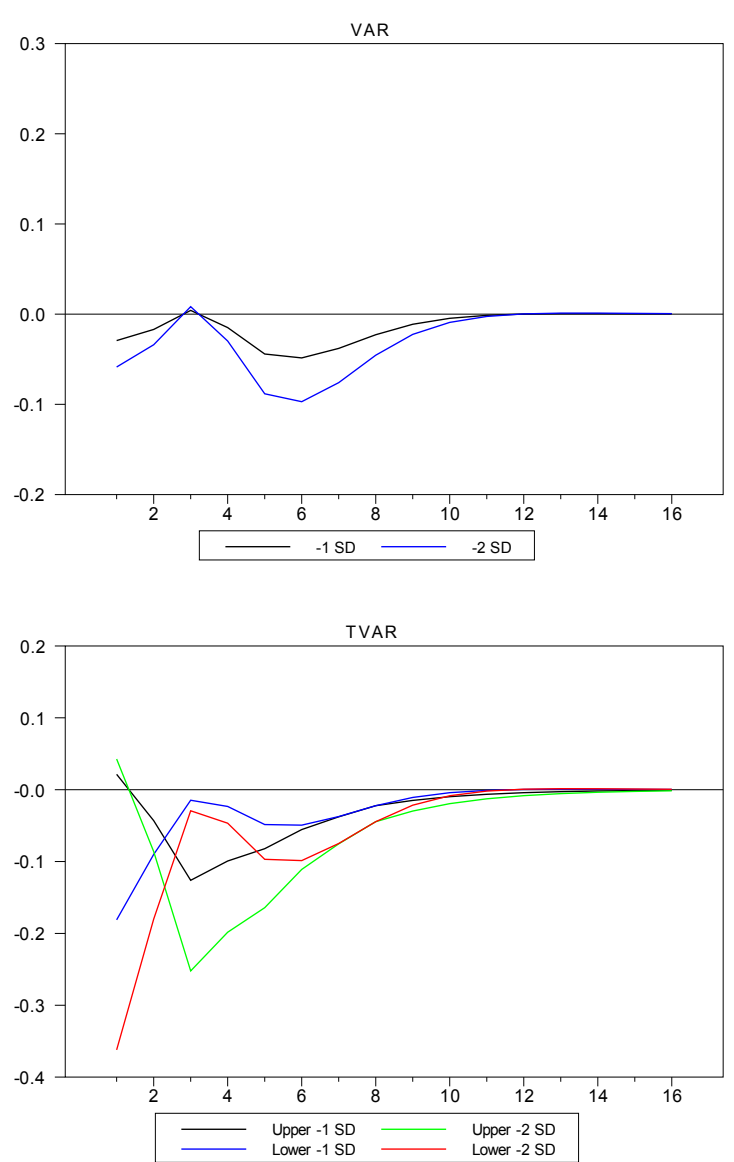

Responses of Output Growth to Islamic Credit Changes Shocks
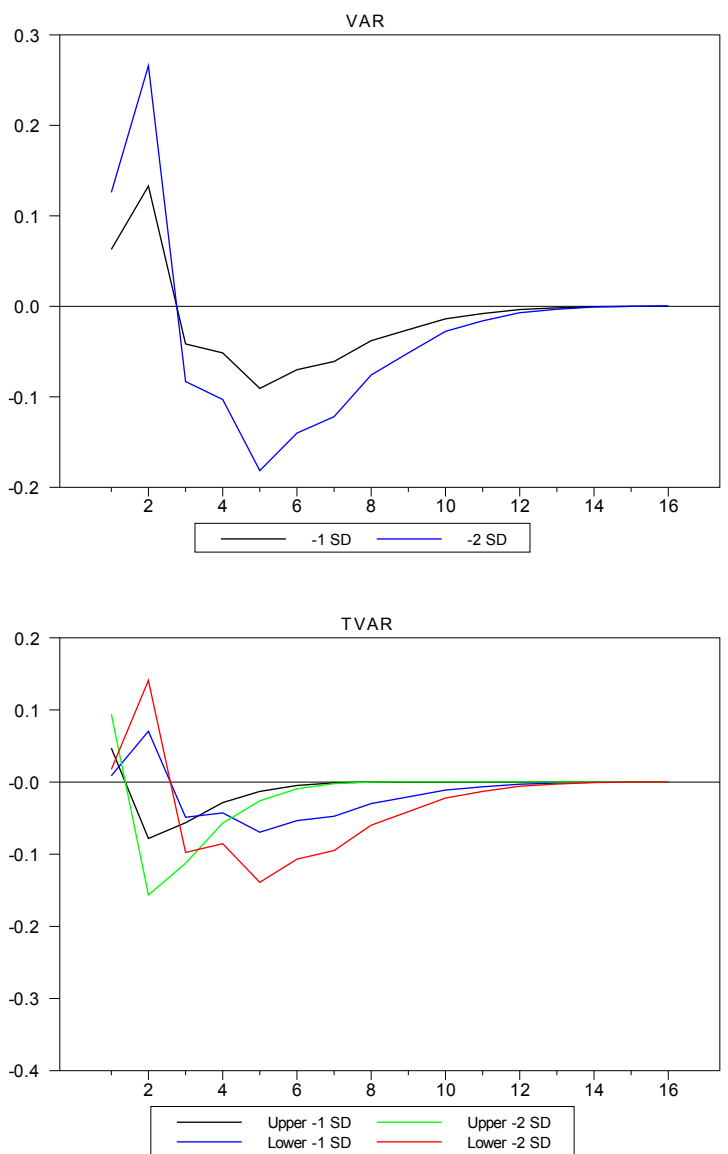

Note: The figures displayed in the left, middle and right panels are obtained from models 1, 2 and 3, respectively. 
Figure 5. Responses of inflation to credit changes shocks.

Responses of Inflation to Total Credit Changes Shocks
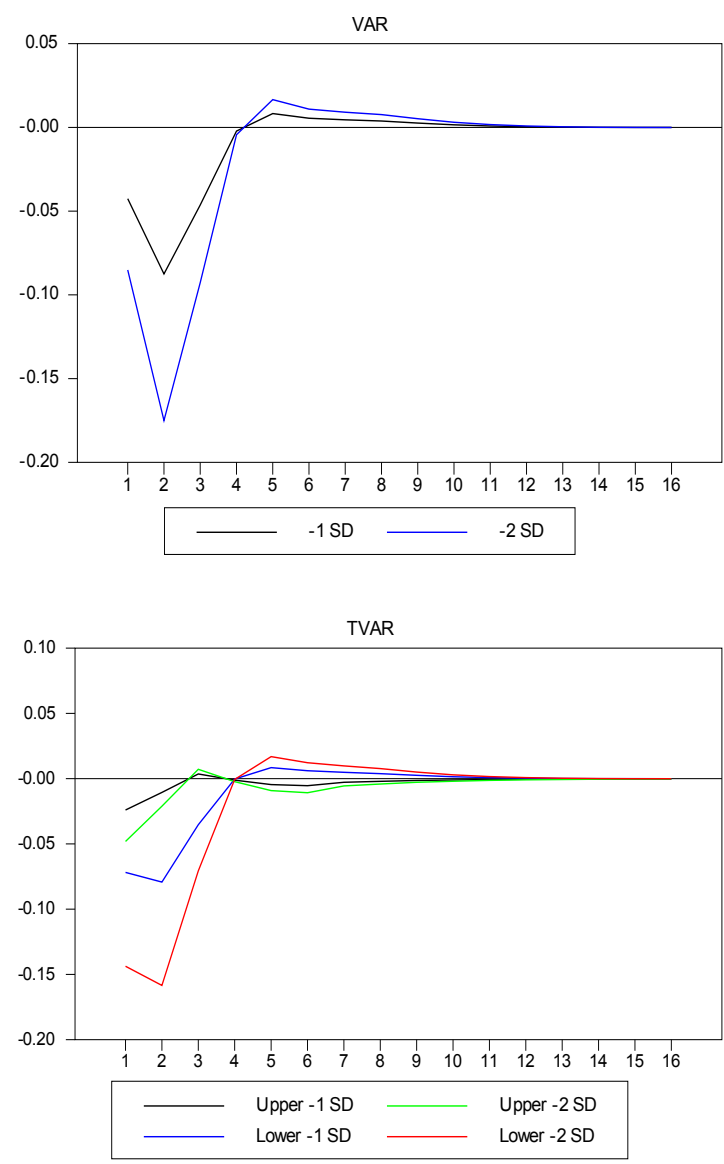

Responses of Inflation to Commercial Credit Changes Shocks

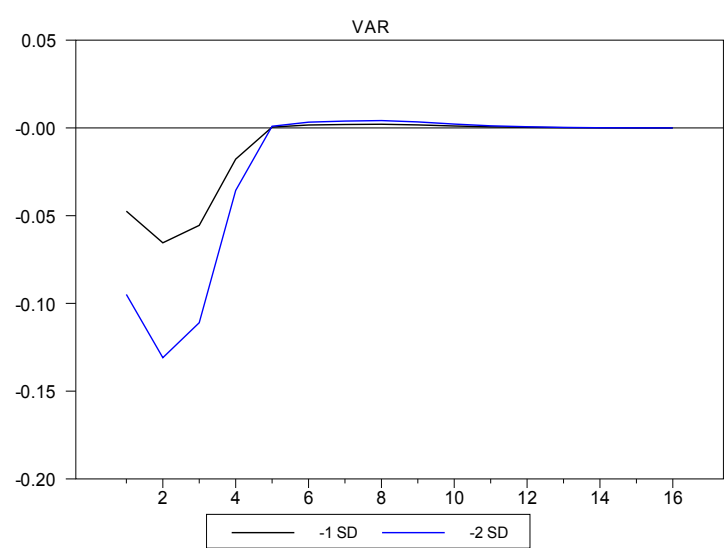

TVAR

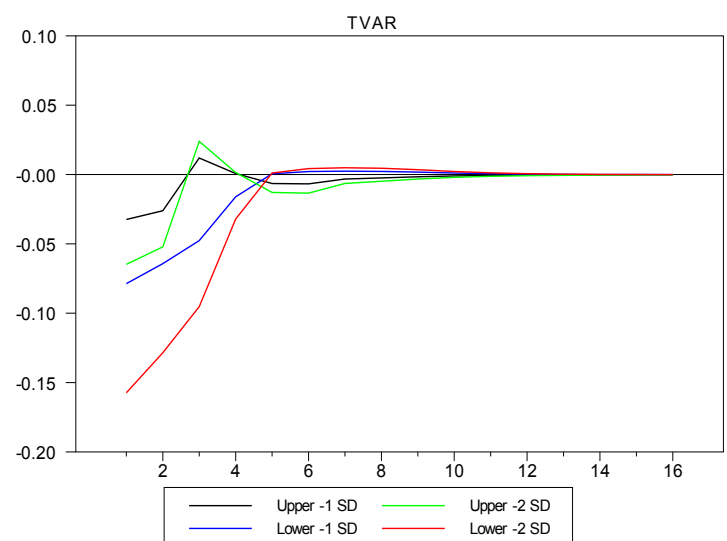

Responses of Inflation to Islamic Credit Changes Shocks

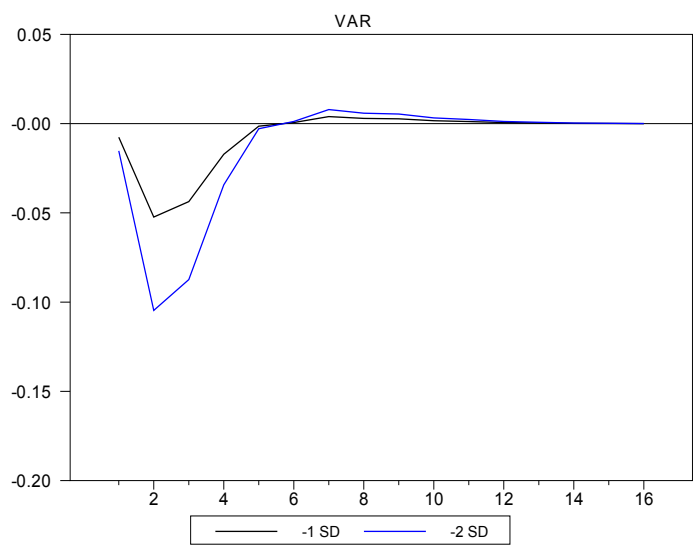

TVAR

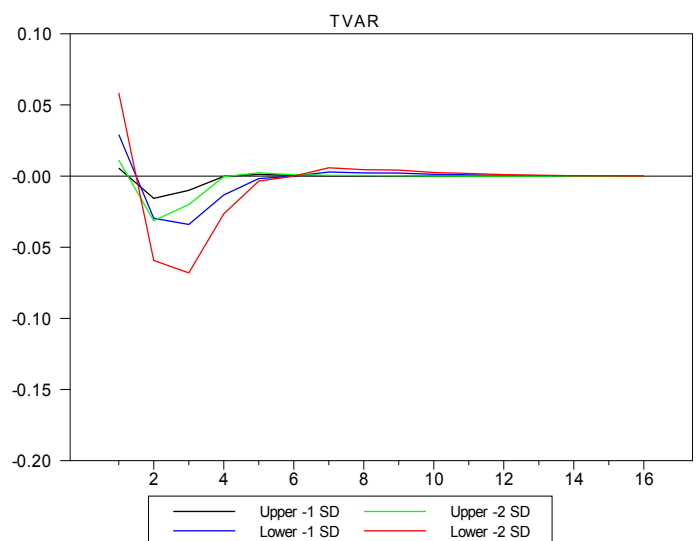

Note: The figures displayed in the left, middle and right panels are obtained from models 1, 2 and 3, respectively. 
Figure 6. Responses of credit changes to interest rate changes shocks.

Responses of Total Credit Changes to Interest Rate Changes Shocks
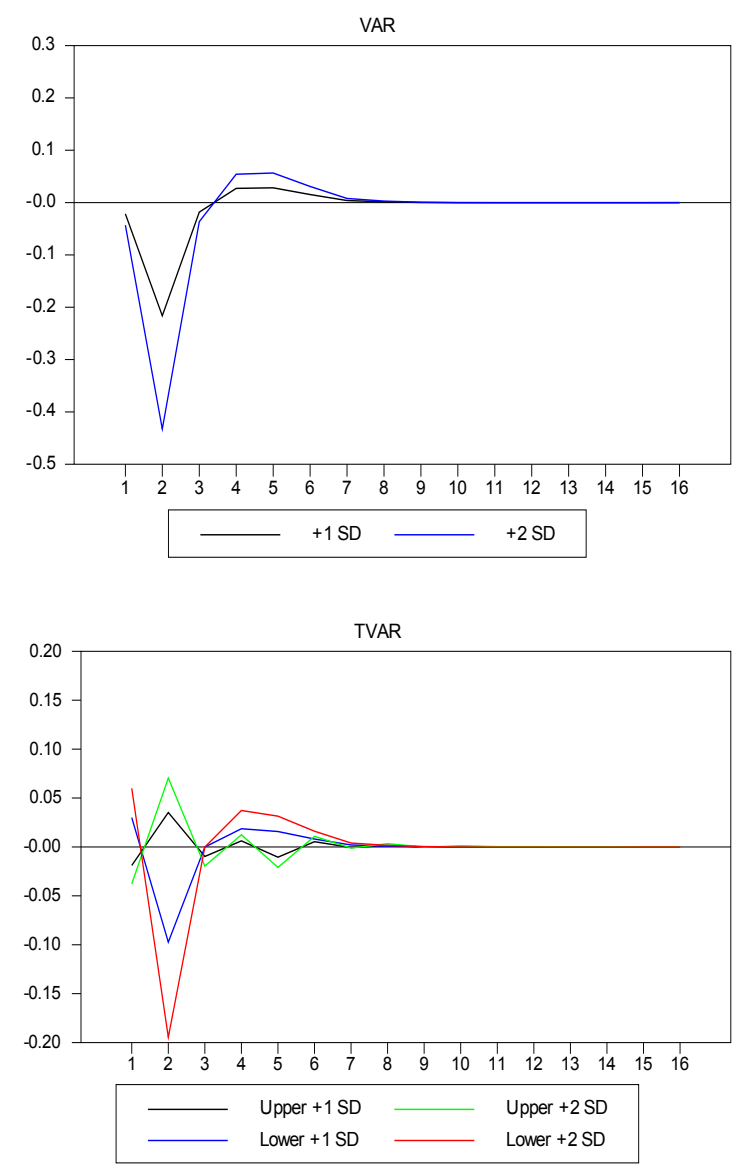

Responses of Commercial Credit Changes to Interest Rate Changes Shocks
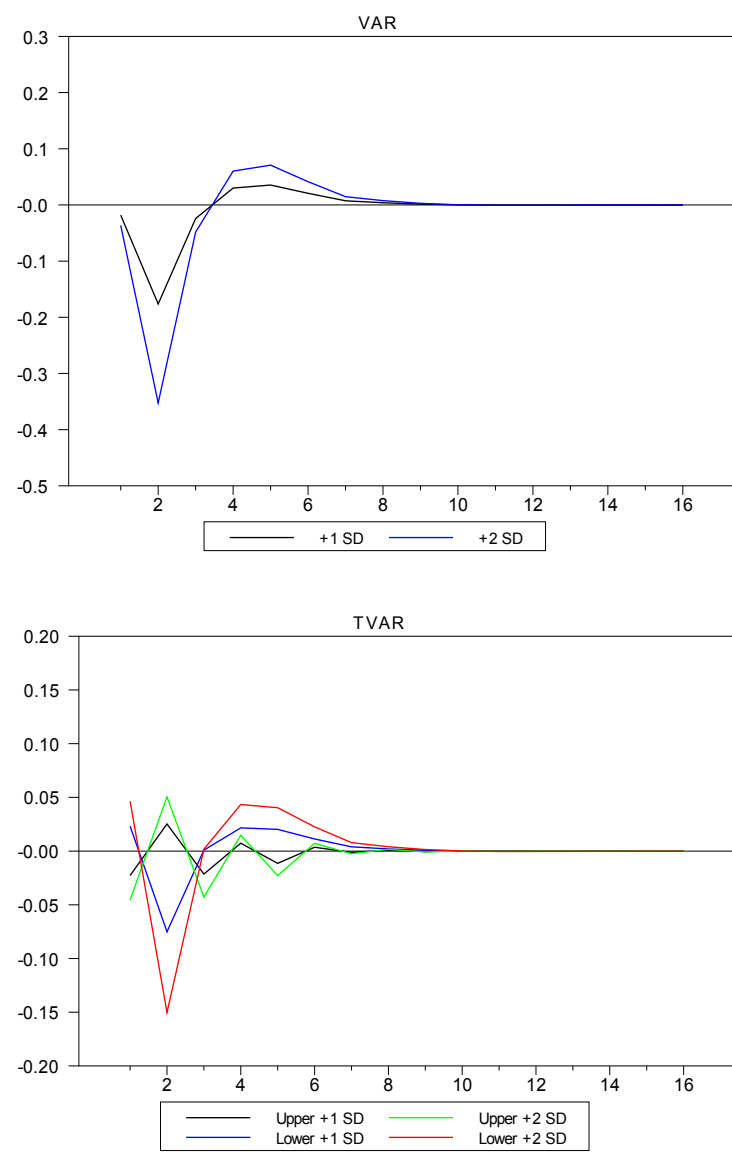

Responses of Islamic Credit Changes to Interest Rate Changes Shocks
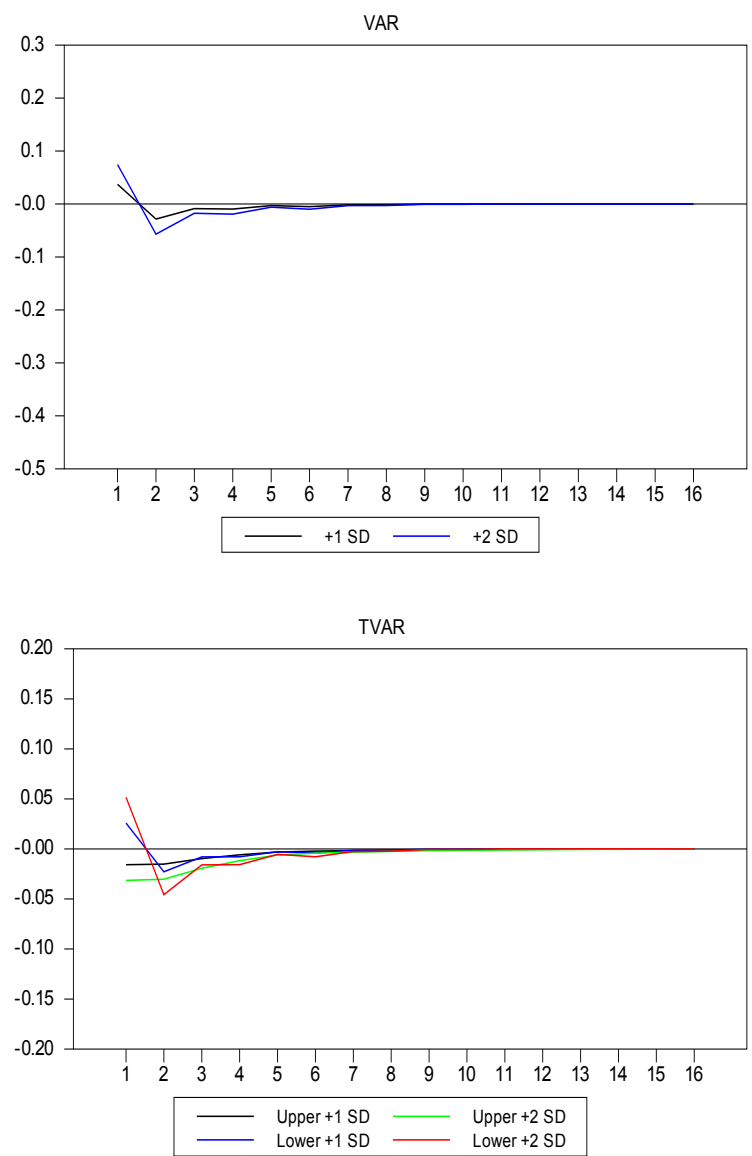

Note: The figures displayed in the left, middle and right panels are obtained from models 1, 2 and 3, respectively. 
Figure 7. Responses of credit changes to money supply changes shocks.

Responses of Total Credit Changes to Money Supply Changes Shocks
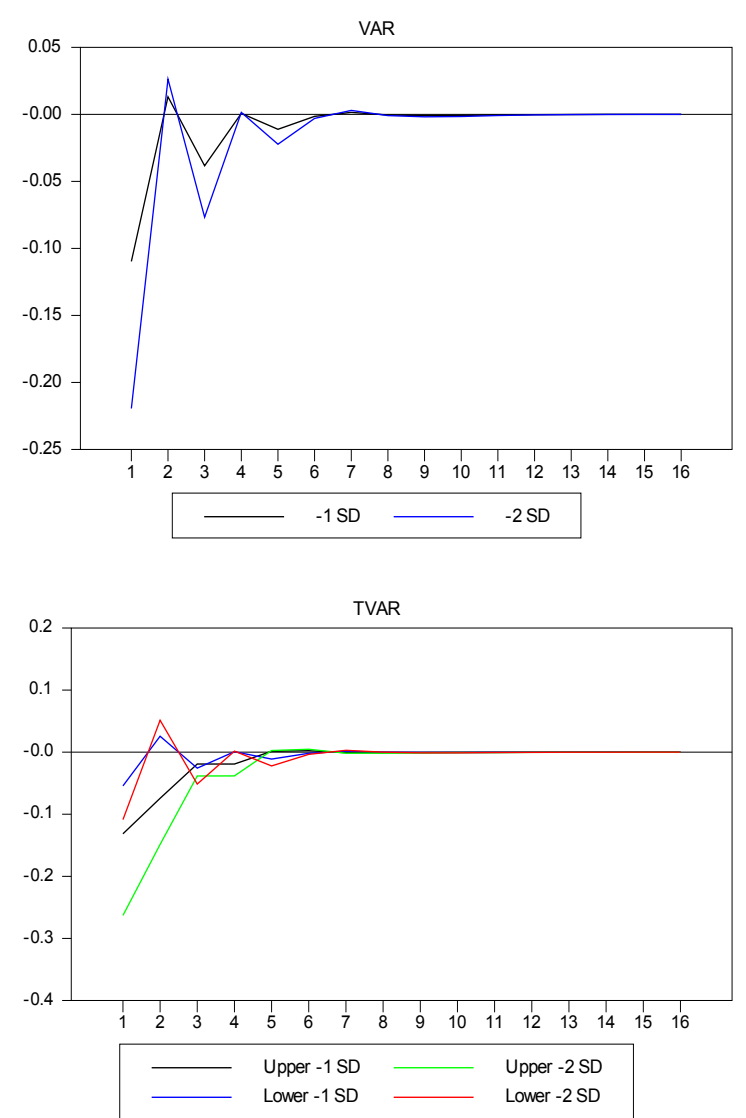

Responses of Commercial Credit Changes to Money Supply Changes Shocks

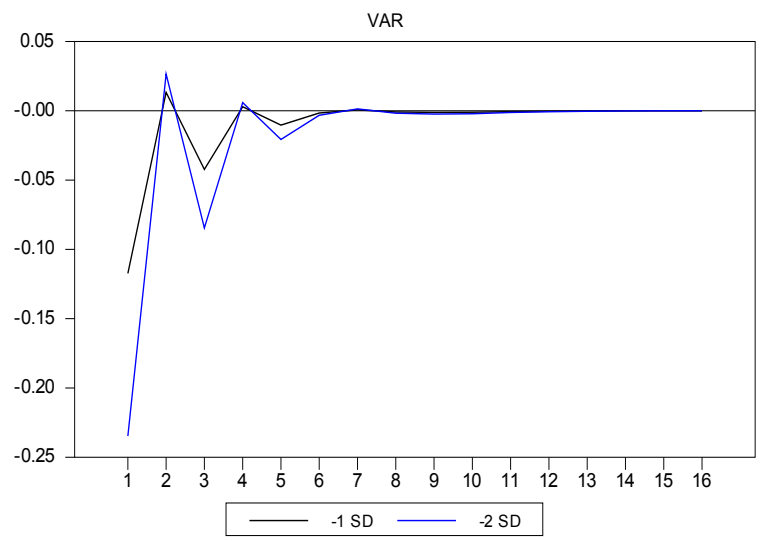

TVAR

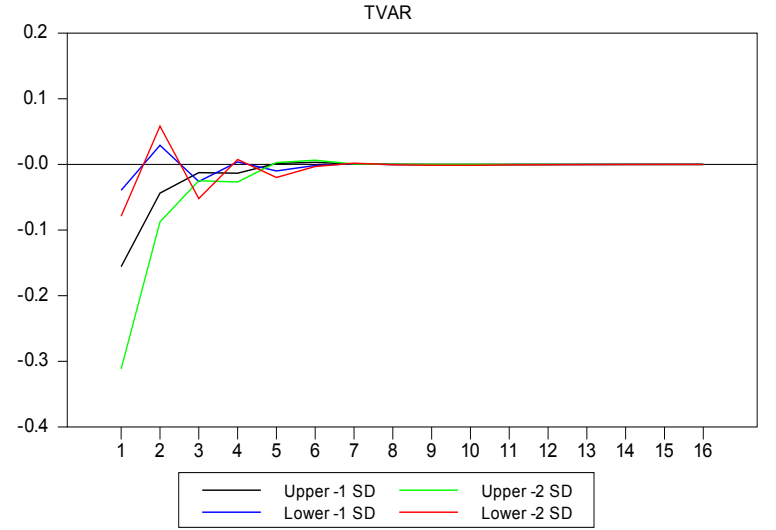

Responses of Islamic Credit Changes to Money Supply Changes Shocks
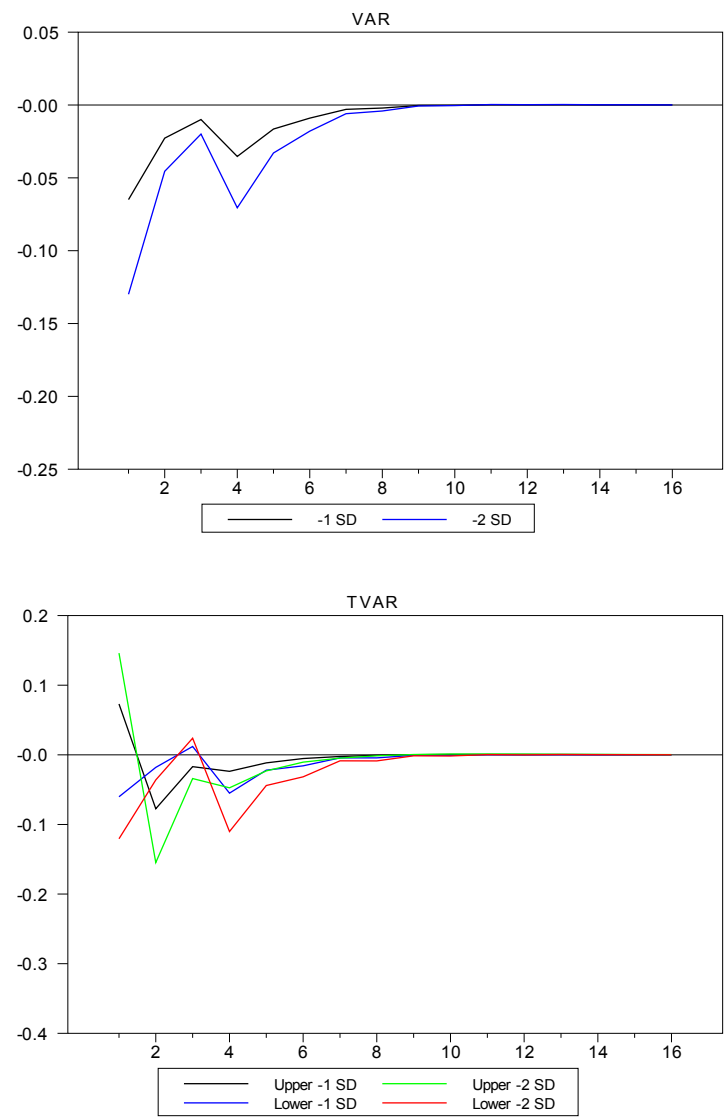

Note: The figures displayed in the left, middle and right panels are obtained from models 1,2 and 3, respectively. 